TID-8531

REACTOR TECHNOLOGY

\title{
COSTS of NUCLEAR POWER
}

(Replaces Report TID-8506 of July 1959)

January 1961

Office of Operations Analysis and Forecasting UNITED STATES ATOMIC ENERGY COMMISSION 


\section{DISCLAIMER}

This report was prepared as an account of work sponsored by an agency of the United States Government. Neither the United States Government nor any agency Thereof, nor any of their employees, makes any warranty, express or implied, or assumes any legal liability or responsibility for the accuracy, completeness, or usefulness of any information, apparatus, product, or process disclosed, or represents that its use would not infringe privately owned rights. Reference herein to any specific commercial product, process, or service by trade name, trademark, manufacturer, or otherwise does not necessarily constitute or imply its endorsement, recommendation, or favoring by the United States Government or any agency thereof. The views and opinions of authors expressed herein do not necessarily state or reflect those of the United States Government or any agency thereof. 


\section{DISCLAIMER}

Portions of this document may be illegible in electronic image products. Images are produced from the best available original document. 
- 


\section{PREFACE}

This report on the costs of nuclear power from stationary plants designed primarily for the generation of electricity deals with those plants in operation, being built, or being designed for construction at an early date. It does not deal with studies of subsequent plants or the role of nuclear power in meeting long-term energy needs. An attempt is made to consider power costs on the basis of consistent definitions and assumptions for the various nuclear plants and for comparable tossil-fuel plants. The report is intended only for information and discussion and does not necessarily represent an official position of the Atomic Energy Commission (AEC) on any of the subjects covered. Comments, corrections, and additions from readers will be welcome.

This report replaces TW-8506, Costs of Nuclear Power, July 1959. Information on several new reactor projects has been included, the capital costs of a number of nuclear power plants have been broken down into major components, and the text and tables have been generally revised and expanded to include new data.

In general, the information used has been that available in the third quarter of calendar year 1960. Principal sources of information have been data submitted by reactor projects and published articles and reports. Considerable assistance in obtaining data has been provided by staff members of the AEC Divisions of Reactor Development and International Affairs and the AEC Operations Offices. Comments and suggestions by readers of TID-8506 have been valuable. This report has been prepared in the AEC Office of Operations Analysis and Forecasting principally by Milton F. Searl on plant costs and Donald W. Kuhn on operating costs, with the assistance of Paul C. Fine, George Y. Jordy, and Ray D. Walton. 
- 


\section{CONTENTS}

PREFACE. . . . . . . . . . . . . . . .

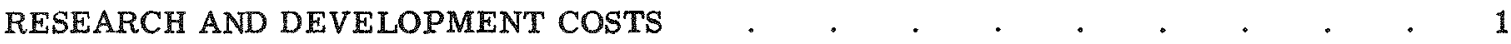

CONSTRUCTION COSTS BY MAJOR CATEGORIES . . . . . . . . . . 4

Land and Land Rights .

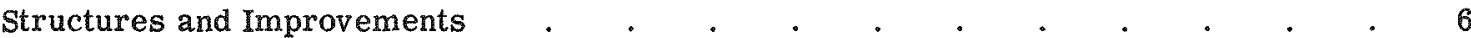

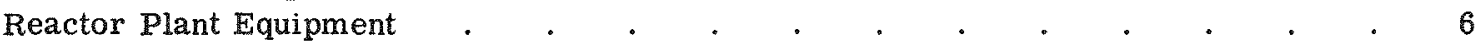

Turbogenerator Units and Accessory Electrical Equipment . . . . . . . $\quad$. 7

Miscellaneous Power Plant Equipment . . . . . . . . . . . . . 7

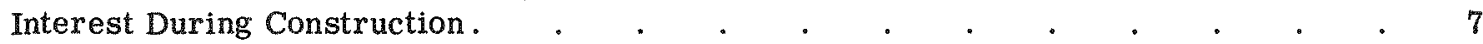

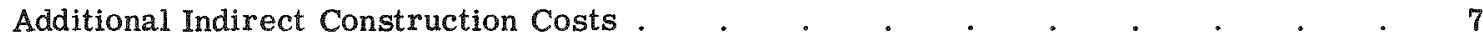

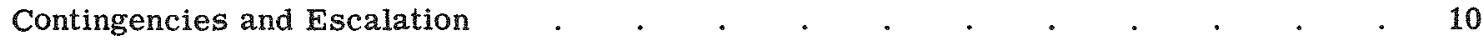

TOTAL CONSTRUCTION COSTS

Reported Costs . . . . . . . . . . . . . . . . . . 10

Estimates vs. Actual Costs . . . . . . . . . . . . . . 11

Variations in Plant Cost with Design Power Level $\quad$. $\quad . \quad$. $\quad . \quad$. $\quad . \quad$. 12

Effect of Surpassing the Design Power Level . . . . . . . . . 14

Thermal Efficiency . . . . . . . . . . . . . . . 15

Variations in Plant Cost with Reactor Type . . . . . . . . . . . . . 17

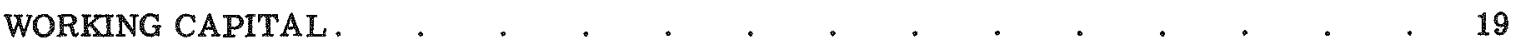

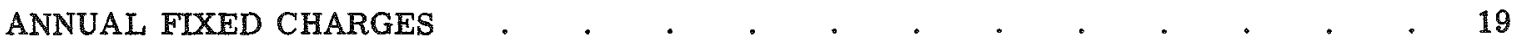

Cost of Money . . . . . . . . . . . . . . . . . . . . 20

Depreciation . $\quad . \quad$. $\quad . \quad$. . . . . . . . . . . 20

Interim Replacements . . . . . . . . . . . . . . . 21

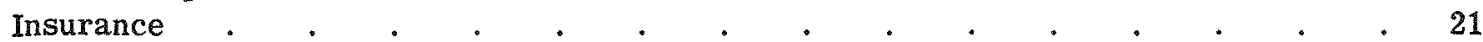

Taxes . . . . . . . . . . . . . . 21

Total Annual Fixed Charges on Plant Investment . . . . . . . . . . 22

Total Annual Fixed Charges on Working Capital . . . . . . . . . $\quad 22$

Plant Factor. . . . . . . . . . . . . . 23

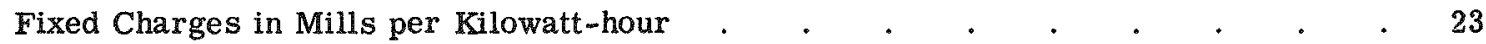

FUEL-CYCLE COSTS •

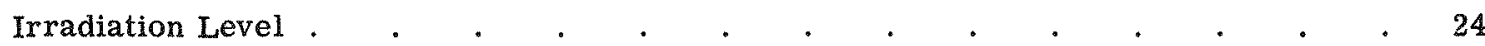

Cost of Fuel-element Fabrication . . . . . . . . . . . . . 25

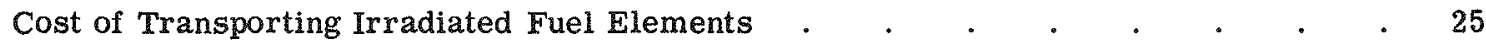

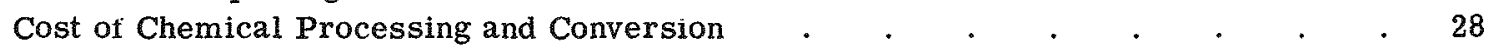

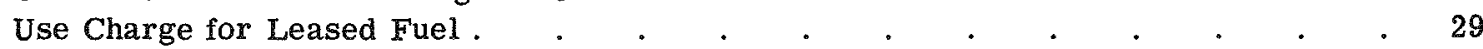

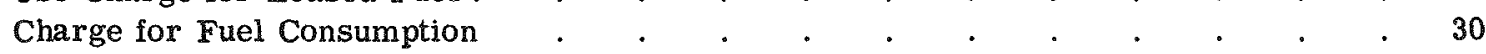


Credit for Plutonium and $\mathrm{U}^{233}$

Total Fuel-cycle Costs . $\quad . \quad$.

COST OF OPERATION AND MAINTENANCE

General. . . . . . . . . . . . . . . . . . . . . 33

Moderator and Coolant Make-up . . . . . . . . . . . . . . 34

TOTAL GENERATING COST . . . . . . . . . . . . . . . 34

OBJECTIVE FOR COMPETITIVE NUCLEAR POWER IN THE

UNITED STATES

APPENDIX: List of Names, Owners and Operators, and

Locations of Nuclear Power Plants 


\section{COSTS OF NUCLEAR POWER}

\section{RESEARCH AND DEVELOPMENT COSTS}

Since most nuclear power plants now in operation, under construction, or planned represent either the first unit of a kind or substantial modifications of previous units, costs of research and development are significant. Table 1 gives estimates of such costs for a number of specific nuclear plants in the United States. As indicated, these costs are often shared between the $A E C$ and the utility when the plant is privately owned. The figures given are mostly for research and development before construction of the plant has been completed. However, in several cases, the $\mathrm{AEC}$ has agreed to share limited costs of research and development after construction and those amounts are included in the figures. Other costs in excess of those for operation of fossil-fuel plants, which are sometimes included in research and development costs, have not been included in Table 1. Not attributable to these specific plants are very large expenditures by the AEC and the nuclear industry in developing the general technology on which these plants are based.

Table 1- ESTIMATED RESEARCH AND DEVELOPMENT COSTS

\begin{tabular}{|c|c|c|c|}
\hline Plant & $\mathrm{AEC}$ & Non-AEC & Total \\
\hline & \multicolumn{3}{|c|}{ Millions of dollars } \\
\hline \multicolumn{4}{|l|}{ Pressurized water } \\
\hline Yankee & 5.0 & 0.3 & 5.3 \\
\hline Indian Point & 0 & 10.8 & 10.8 \\
\hline \multicolumn{4}{|l|}{ Boiling water } \\
\hline Big Rock Point & 4.6 & 0 & 4.6 \\
\hline Pathfinder & 8.5 & 0 & 8.5 \\
\hline BONUS & 0.9 & 0.2 & 1.1 \\
\hline \multicolumn{4}{|l|}{ Gas cooled } \\
\hline Peach Bottom & 14.5 & 5.6 & 20.1 \\
\hline Florida & 11.6 & 12.5 & 24.1 \\
\hline \multicolumn{4}{|l|}{ Heavy water cooled } \\
\hline Carolinas-Virginia & 13.9 & 1.9 & 15.8 \\
\hline \multicolumn{4}{|l|}{ Organic } \\
\hline Piqua & 3.5 & 0 & 3.5 \\
\hline \multicolumn{4}{|l|}{ Sodium graphite } \\
\hline Hallam & 16.0 & 0 & 16.0 \\
\hline \multicolumn{4}{|l|}{ Fast breeder } \\
\hline Fermi & 4.5 & 20.7 & 25.2 \\
\hline
\end{tabular}

Indications are that rate-making bodies will allow utilities to treat expenditures for research and development as operating expenses over a period of a few years.* Therefore these expenditures, unlike plant construction costs, will not result in continuing charges over the

* See report TID-8208, State Regulation and the Future of Nuclear Power, June 1960, by Ray E. Untereiner. 
Table 2-REPORTED CONSTRUCTION COSTS BY MAJOR CATEGORIES FOR SPECIFIC NUCLEAR POWER PLANTS

\begin{tabular}{|c|c|c|c|c|c|c|c|c|c|c|}
\hline Plant type and name & $\begin{array}{l}\text { Land } \\
\text { and land } \\
\text { rights }\end{array}$ & $\begin{array}{c}\text { Structures } \\
\text { and improve- } \\
\text { ments }\end{array}$ & $\begin{array}{l}\text { Reactor } \\
\text { plant } \\
\text { equip- } \\
\text { ment }\end{array}$ & $\begin{array}{c}\text { Turbo- } \\
\text { generator } \\
\text { and accessory } \\
\text { equipment }\end{array}$ & $\begin{array}{l}\text { Misc. } \\
\text { power } \\
\text { plant } \\
\text { equipment }\end{array}$ & $\begin{array}{l}\text { Interest } \\
\text { during } \\
\text { construc- } \\
\text { tion }\end{array}$ & $\begin{array}{l}\text { Additional } \\
\text { indirect } \\
\text { construc- } \\
\text { tion costs }\end{array}$ & $\begin{array}{l}\text { Contin- } \\
\text { gencies }\end{array}$ & $\begin{array}{c}\text { Escala- } \\
\text { tion }\end{array}$ & Total \\
\hline & \multicolumn{10}{|c|}{ Millions of dollars } \\
\hline \multicolumn{11}{|l|}{ Pressurized water } \\
\hline SM-1 & $\mathrm{a}$ & 1.4 & 1.3 & 0.87 & 0.04 & $\mathrm{~b}$ & 0.3 & $c$ & $c$ & 3.9 \\
\hline Shippingport & d & 14.6 & 18.8 & 9.8 & 2.3 & $2.3^{b}$ & $25.1^{\mathrm{e}}$ & c & $c$ & 72.9 \\
\hline Yankee & 0.2 & 6.8 & 13.0 & 8.8 & 0.2 & 3.0 & $13.4^{f}$ & \multicolumn{2}{|c|}{$\longrightarrow 6.6 \longrightarrow$} & 52.0 \\
\hline SELNI (Italy) & -9 & $5 \longrightarrow$ & 18.5 & \multicolumn{2}{|c|}{$-11.4-$} & - & $+\infty$ & 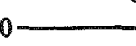 & $\longrightarrow$ & 56.4 \\
\hline Indian Point & 0.4 & 24.1 & 30.0 & 24.9 & 0.4 & 5.1 & 4.6 & 8 & 8 & 89.5 \\
\hline \multicolumn{11}{|l|}{ Boiling water } \\
\hline EBWR $^{h}$ & a & 1.2 & 1.9 & 1.0 & 0.1 & $\mathrm{~b}$ & 0.4 & $c$ & $c$ & 4.6 \\
\hline BONUS & 0.3 & 1.8 & 2.9 & 1.7 & 0.3 & $0.1^{b}$ & 2.5 & 2.7 & 0.4 & $12.7^{i}$ \\
\hline Elk River & d & 1.8 & 4.2 & $1.7^{\mathrm{j}}$ & 0.05 & $\mathrm{~b}$ & 4.5 & $\mathrm{k}$ & k & 12.2 \\
\hline Humboldt Bay & a & 2.9 & 8.8 & 5.2 & 0.3 & \multicolumn{2}{|c|}{$\longrightarrow 2.3 \longrightarrow$} & $g$ & d & $19.5^{1}$ \\
\hline Big Rock Point & 0.15 & 6.0 & 11.1 & 5.6 & 0.5 & 1.8 & 1.0 & 0.5 & $\mathrm{~m}$ & 26.7 \\
\hline Pathfinder & 0.4 & 3.1 & 7.6 & 6.4 & 0.3 & $d$ & 0.9 & 2.0 & 1.1 & 21.8 \\
\hline SENN (Italy) & 0.6 & 4.0 & 23.6 & 7.7 & 0.8 & 8.8 & 13.0 & 1.1 & 3.6 & 63.2 \\
\hline \multicolumn{11}{|l|}{ Gas cooled } \\
\hline EGCR & a & 8.0 & 10.6 & $2.8^{\mathrm{n}}$ & 0.1 & $b$ & 7.6 & 1.5 & d & $\$ 0.6$ \\
\hline Peach Bottom & 0.4 & 2.6 & 14.1 & 5.4 & 0.7 & 1.2 & 3.4 & 8 & $\mathrm{~g}$ & 27.8 \\
\hline Florida $^{\circ}$ & 0.3 & 4.5 & $9.3^{\mathrm{P}}$ & 4.2 & 0.4 & 2.0 & 3.9 & 2.1 & 1.9 & 28.6 \\
\hline \multicolumn{11}{|l|}{ Heavy water cooled } \\
\hline Carolinas-Virginia & 0.05 & 3.1 & $10.7^{p}$ & $0,9^{q}$ & 0.3 & 1.4 & $0.6^{\underline{x}}$ & $\mathrm{~d}$ & 0.6 & 17.7 \\
\hline CANDU (Canada) & 0.9 & 5.0 & $22.9^{\mathrm{s}}$ & 13.2 & 3.3 & 9.2 & 14.2 & 8.6 & 4.2 & 81.5 \\
\hline \multicolumn{11}{|l|}{ Organic } \\
\hline Piqua ${ }^{t}$ & $0.0035^{\mathrm{u}}$ & 2.8 & 2.8 & 3.2 & 0.5 & $b$ & 1.5 & 0.2 & 0.8 & 11.8 \\
\hline \multicolumn{11}{|l|}{ Sodium graphite } \\
\hline SRE & $d$ & 1.9 & 4.5 & 2.0 & 0.2 & $\mathrm{~b}$ & d & $c$ & c & 8.6 \\
\hline Hallam & 0.1 & 7.1 & 17.5 & 10.1 & 2.2 & $0.6^{\mathrm{b}}$ & 5.0 & 0.4 & $\mathrm{v}$ & $43.0^{w}$ \\
\hline \multicolumn{11}{|l|}{ Fast breeder } \\
\hline $\mathrm{EBR}-\mathrm{II}^{\mathrm{X}}$ & a & 7.5 & 9.0 & 3.0 & 0.5 & $\mathrm{~b}$ & 3.6 & 1.7 & y & 25.3 \\
\hline Fermi & 0.9 & 8.6 & 21.0 & 8.2 & 2.1 & 2.2 & $11.9^{2}$ & 1.4 & 8 & 56.3 \\
\hline
\end{tabular}


${ }^{2}$ Cost of land and land rights has not been included when the plant is located at a pre-existing site.

${ }^{b}$ Interest during construction has not been included in this table for the AEC portion of construction costs.

${ }^{\mathrm{c}}$ Not applicable, since plant construction has been completed and actual costs are given for the other items.

Not available.

${ }^{\mathrm{e}}$ Includes $\$ 2.9$ million for net cost of preliminary operation.

Includes $\$ 3.2$ million for startup and one year of test operation.

Included by distribution among other categories.

${ }^{h}$ Does not include $\$ 2.1$ million for recent modifications to increase the capacity to $100 \mathrm{Mw}(\mathrm{t})$.

${ }^{i}$ Recent information indicates a total construction cost of $\$ 12.1$ million, which is used in Table 4.

includes cost of pre-existing turbine-generator.

${ }^{k}$ AEC portion ( 75 per cent) of costs shown under other categories is based on ceiling amount of AEC contract with manufacturer.

${ }^{1}$ Based on prices in first quarter of 1958 . Recent information indicates a total construction cost of $\$ 20.6$ million, which is used in Table 4 .

${ }^{m}$ Costs given are ceiling amounts under the contract.

Includes $\$ 0.25$ million as remaining book value of a pre-existing turbine-ngenerator.

${ }^{\circ}$ Based on design using fuel elements clad with stainless steel. Work is now being done on beryllium cladding.

${ }^{P}$ Does not include cost of heavy water, which is to be leased.

${ }^{q}$ Does not include cost of pre-existing turbine-generator.

Includes start-up cost of $\$ 0.2$ million.

s Includes $\$ 11.7$ million for heavy water, helium, and organic fluids.

${ }^{t}$ Includes turbogenerator unit rated at $33 \mathrm{Mw}(\mathrm{e})$ and complete structure for an additional turbogenerator unit, although the gross capacity of the plant as designed is only $12.5 \mathrm{Mw}(\mathrm{e})$.

${ }^{u}$ Cost of the site proper, not including a surrounding buffex zone.

$\checkmark$ Cost given for reactor plant equipment includes $\$ 0.5$ million for escalation

wecent information indicates a total construction cost of $\$ 45$ million, which is used in Table 4.

${ }^{x}$ Does not include $\$ 7.1$ million for fuel-cycle facility. Recent information indicates an increase of $\$ 1.3 \mathrm{million}$ in the total cost of the EBR-10.

$\checkmark$ Some contracts are fixed cost while others are subject to escalation; construction is over 75 per cent complete.

${ }^{2}$ Obtained by subtracting the other categories listed for Fermi from the total of $\$ 56.3$ million. The latter amount is the total plant cost minus the costs of research and development and fuel-element fabrication, as given in the Fourth Semiannual Financial Report of the Power Reactor Development $\mathrm{Co}$. Included is $\$ 0.8$ million for nonnuclear testing and employee training but not the cost of nuclear testing. 
life of the plant and are not included in this report in computing costs of nuclear power in mills per kilowatt-hour.

\section{CONSTRUCTION COSTS BY MAJOR CATEGORIES}

This section deals with major categories of cost in the construction of nuclear power plants. Not included are costs of research and development, training, nuclear fuel, fuel fabrication, electric substation, and transmission lines. The categories used here are based on the classification for nuclear plants in the revised System of Accounts published by the Federal Power Commission (FPC) in the Federal Register for May 14, 1959.

Sources of information are estimates, contract prices, and actual costs in a few cases. The figures depend on size, design, and location of the plant; date and purpose of the estimate or contract; degree of conservatism; and interpretation of items included in each cost category. Consequently, figures from different sources are often not comparable. Moreover, a breakdown of costs is not available for a number of projects. However, available data on cost categories have been collected in Table 2, shown as costs per kilowatt in Table 3 (except for plants that are primarily experimental), and discussed in this section. Total construction costs are discussed in the next section. Nuclear plants often contain equipment and instrumentation not necessary for power generation, and plant costs are considerably increased by the inclusion of these facilities.

Comparisons are made with corresponding construction costs for modern fossil-fuel plants. One source of this information is the Eleventh Steam Station Cost Survey published in the journal, Electrical World, for Oct. 5, 1959, which gives data for 53 stations having capacities from 22 to $842 \mathrm{Mw}(\mathrm{e})$ and starting operations from 1949 to 1958 . Costs are given by major categories, except that indirect construction costs have been distributed among other categories. These plant costs depended on location, date and type of construction, kind of fossil fuel used, and number of generating units per station. Another source of information is an engineering design study made for the AEC and published as report SL-1564.* This report gives estimated costs for the first and second units of coal-fired stations of five different unit capacities from 25 to $325 \mathrm{Mw}$ (e) (nameplate ratings), based on an assumed location in the Middle West and prices prevailing at the end of 1958 .

\section{Land and Land Rights}

The costs of land and land rights (FPC Account 320) for nuclear power plants are affected by the safety rules being applied. In determining the site of a nuclear plant, detailed consideration must be given to meteorology, climate, hydrology, geology, and seismology, and to the population distribution in the environs. The site consists of an exclusion area that usually has a minimum radius of $1 / 4$ to $3 / 4$ mile and covers 100 to 1000 acres or more, but this depends on the reactor capacity, other plant features, and local conditions. For example, for the Piqua reactor the site proper contains only 3.34 acres but it is surrounded by a buffer zone including adjacent property under the control of the City of Piqua, a quarry, and the Miami River. Since nuclear power plants are located in areas of low population density, the cost per acre of land may be less but costs associated with longer transmission lines may be greater than for conventional steam plants.

The costs of land and land rights given in Table 3 do not follow any clear pattern. They vary from $\$ 1.30$ to $\$ 18.40$ per net electrical kilowatt of installed capacity, except for the low figure for Piqua. In some cases, these costs may be reduced in the future by installation of additional plants at the same site. For conventional steam plants, land costs per electrical kilowatt ranged from $\$ 0.09$ to over $\$ 11$ for stations in the Electrical World survey, were less than $\$ 1$ for half of those stations, and were assumed to be less than $\$ 1$ in the engineering study of report SL-1564. It therefore appears that land costs tend to be higher for nuclear than for conventional plants.

* Nuclear-Conventional Power Plant Cost Study: Conventional Coal Fired Power Plants: 25,000 KW to 325,000 KW, Sargent and Lundy, Chicago, Mar. 2, 1959 (AECU-4140). 
Table 3-CONSTRUCTION COSTS PER UNIT CAPACITY FOR SPECIFIC NUCLEAR POWER PLANTS*

\begin{tabular}{|c|c|c|c|c|c|c|c|c|c|c|c|}
\hline \multicolumn{2}{|l|}{ Plant } & \multirow{2}{*}{$\begin{array}{l}\text { Land } \\
\text { and land } \\
\text { rights }\end{array}$} & \multirow{2}{*}{$\begin{array}{c}\text { Structures } \\
\text { and improve- } \\
\text { ments }\end{array}$} & \multirow{2}{*}{$\begin{array}{l}\text { Reactor } \\
\text { plant } \\
\text { equip- } \\
\text { ment }\end{array}$} & \multirow{2}{*}{$\begin{array}{c}\text { Turbo- } \\
\text { generator } \\
\text { and accessory } \\
\text { equipment }\end{array}$} & \multirow{2}{*}{$\begin{array}{l}\text { Misc. } \\
\text { power } \\
\text { plant } \\
\text { equipment }\end{array}$} & \multirow{2}{*}{$\begin{array}{l}\text { Interest } \\
\text { during } \\
\text { construc- } \\
\text { tion }\end{array}$} & \multirow{2}{*}{$\begin{array}{l}\text { Additional } \\
\text { indirect } \\
\text { construc- } \\
\text { tion costs }\end{array}$} & \multirow[b]{2}{*}{$\begin{array}{l}\text { Contin- } \\
\text { gencies }\end{array}$} & \multirow[b]{2}{*}{$\begin{array}{l}\text { Escala- } \\
\text { tion }\end{array}$} & \multirow[b]{2}{*}{ Total $\uparrow$} \\
\hline Type and naine & $\begin{array}{c}\text { Net elec. } \\
\text { megawatts }\end{array}$ & & & & & & & & & & \\
\hline & & \multicolumn{10}{|c|}{ Dollars per net electrical kilowatt } \\
\hline \multicolumn{12}{|l|}{ Pressurized water } \\
\hline Yankee & $110-136$ & $1.8-1.5$ & $62-50$ & $118-95$ & $80-64$ & $1.9-1.5$ & $27-22$ & $122-98$ & \multicolumn{2}{|c|}{$\longleftarrow 60-49 \longrightarrow$} & $470-380$ \\
\hline SELNI (Italy) & 176 & & $-54 \longrightarrow$ & 105 & -65 & $\longrightarrow$ & & & & & 320 \\
\hline Indian Point & 255 & 1.5 & 95 & 118 & 98 & 1.8 & 20 & 18 & & & 350 \\
\hline \multicolumn{12}{|l|}{ Boiling water } \\
\hline BONUS & 16.3 & 18.4 & 112 & 178 & 106 & 16 & 7 & 156 & 159 & 25 & 780 \\
\hline Elk River & 22 & & 80 & 191 & 75 & 2.3 & & 204 & & & 550 \\
\hline Humboldt Bay & 48.5 & & 59 & 182 & 108 & 5.9 & $-47-$ & $\longrightarrow$ & & & 400 \\
\hline Big Rock Point & $48.5-72.8+$ & $3.1-2.1$ & $125-83$ & $228-152$ & $116-78$ & $11-7$ & $37-25$ & $20-14$ & $10-7$ & & $550-370$ \\
\hline Pathfinder & 62 & 7.3 & 49 & 123 & 104 & 4.8 & & 14 & 32 & 17 & 350 \\
\hline SENN (Italy) & 150 & 4.0 & 27 & 157 & 51 & 5.3 & 59 & 87 & 7 & 24 & 420 \\
\hline \multicolumn{12}{|l|}{ Gas cooled } \\
\hline Peach Bottom & 40 & 11.0 & 65 & 351 & 136 & 18 & 30 & 85 & & & 700 \\
\hline Florida & 50.5 & 6.3 & 89 & 185 & 83 & 7 & 39 & 78 & 41 & 37 & 570 \\
\hline \multicolumn{12}{|l|}{ Heavy water cooled } \\
\hline Carolinas-Virginia & 17 & 2.7 & 181 & 628 & 54 & 17 & 85 & 37 & & 36 & 1040 \\
\hline CANDU (Canada) & 200 & 4.4 & 25 & 114 & 66 & 17 & 46 & 71 & 43 & 21 & 410 \\
\hline \multicolumn{12}{|l|}{ Organic } \\
\hline Piqua & 11.4 & 0.3 & 250 & 241 & 280 & 43 & & 129 & 19 & 74 & 1040 \\
\hline \multicolumn{12}{|l|}{ Sodium graphite } \\
\hline Hallam & $75-87$ & $1.6-1.3$ & $95-81$ & $233-201$ & $135-116$ & $29-25$ & $7.6-6.5$ & $67-58$ & $5-4$ & & $570-490$ \\
\hline \multicolumn{12}{|l|}{ Fast breeder } \\
\hline Fermi & $91-143$ & $9.7-6.2$ & $95-60$ & $231-147$ & $91-58$ & $23-15$ & $24-15$ & $129-82$ & $16-10$ & & $620-390$ \\
\hline
\end{tabular}

* Plants are those listed in Table 2 with the same footnotes applying, except that primarily experimental plants are not included. The numbers in Table 3 have been computed from the original data rather than from the rounded figures in Table 2 .

$\uparrow$ Rounded to the nearest $\$ 10 / \mathrm{kw}$. As stated in footnotes of Table 2 , recent information indicates somewhat different total costs of construction for BONUS, Humboldt Bay, and Hallam and those costs are used in Table 4.

$\$$ Net capacity of Big Rock Point has been estimated for purposes of this report at 97 per cent of gross capacity. 


\section{Structures and Improvements}

The costs of structures and improvements (FPC Account 321) cover site preparation, housing for reactor plant equipment and turbogenerator units, and laboratory, office, and other buildings. Shielding required around those portions of a nuclear plant containing radioactive materials adds to the cost of structures. Further costs arise from measures to contain radioactivity in case of accident, such as a steel and concrete gas-tight structure around the reactor, air locks for entrances and exits, a ventilation and filter system, and a spray system. With additional operating experience, it may be possible to eliminate some of these measures in future plants or to reduce their costs.

The costs of structures and improvements given in Table 3 range from $\$ 25$ to $\$ 125$ per net electrical kilowatt of installed capacity, except that the figures are higher for the CarolinasVirginia and Piqua plants. Estimated costs may be increased by allowances for contingencies and escalation. No definite relation to plant size or type is apparent because of variations in other factors. For the conventional steam plants included in the survey by Electrical World, costs of structures and improvements per electrical kilowatt range from about $\$ 7$ to $\$ 60$, except for one at $\$ 3$ and another at $\$ 100$; costs tend to be reduced by outdoor type construction. For the first unit of a two-unit conventional station considered in report SL-1564, the estimates vary from $\$ 71$ per net electrical kilowatt for a nameplate rating of $25 \mathrm{Mw}$ to $\$ 24$ for $325 \mathrm{Mw}$; the additional costs for the second unit were estimated to range from $\$ 39$ for $25 \mathrm{Mw}$ to $\$ 18$ for $325 \mathrm{Mw}$. It therefore appears that costs of structures and improvements are usually higher for nuclear than for conventional plants of the same capacity.

\section{Reactor Plant Equipment}

The costs of reactor plant equipment (FPC Account 322) cover all the items required for the generation of steam, except the fuel elements. Included are cooling and moderator materials, such as heavy water (if purchased rather than leased), sodium, and graphite. Also included are the reactor pressure vessel and equipment for controlling the reactor, handling fuel, supplying coolant, and disposing of waste, as well as heat exchangers, steam generators, pumps, piping, and instrumentation.

The costs of reactor plant equipment given in Table 3 range from $\$ 95$ to $\$ 351$ per net electrical kilowatt, except that the figure for the Carolinas-Virginia plant is higher. The costs of the corresponding category for conventional plants, boiler plant equipment, vary from about $\$ 30$ to $\$ 100$ per kilowatt according to the Electrical World survey. In report SL-1564 the cost of boiler plant equipment per net electrical kilowatt is estimated to range from $\$ 62$ at $325 \mathrm{Mw}$ to $\$ 99$ at $25 \mathrm{Mw}$ for a single unit and from $\$ 60$ to $\$ 81$ for a second unit of the same capacity. It is clear that reactor plant equipment is more expensive than boiler plant equipment.

For heavy-water reactors, the value of the heavy-water inventory is a substantial item. It has been included in the cost given for the CANDU plant and amounts to $\$ 59$ per net electrical kilowatt. (The corresponding figure for the NPD-2 prototype is $\$ 88$ per kilowatt.) It would be at least $\$ 110$ per kilowatt for the Carolinas-Virginia plant, but has not been included because the heavy water for this plant is now under lease.

Increased power output and other technical improvements as well as manufacturing and operating experience over the next decade should result in significant reductions in the costs per kilowatt for reactor plant equipment. For example, the Consolidated Edison Company of New York has estimated that, if its plant under construction at Indian Point were duplicated at the same site, the cost of the nuclear portion would be reduced by one-third.

Superheating steam from a nuclear reactor or from a conventional boiler improves the thermal efficiency and usually the economy of power production. Steam is to be superheated in the Indian Point nuclear plant by burning oil and in the Elk River plant by burning coal. The Pathfinder and BONUS plants will superheat steam by passing it back through a higher temperature portion of the reactor core. Another possibility is to use a separate reactor as a superheater. Further technical developments in reactor plant equipment should permit significant increases in operating temperatures and thermal efficiencies of nuclear plants, with consequent reductions in costs per kilowatt. 
The costs of turbogenerator units (FPC Account 323) and accessory electrical equipment (FPC Account 324) cover the equipment for converting thermal to electrical energy and the associated switchboards, protective equipment, conduits, power and control wiring, and electrical service equipment for the station, but not the substation or transmission lines. The cost of the accessory electrical equipment is normally about one-fourth as great as the cost of the turbogenerator units. For the nuclear plants listed in Table 3, combined costs for these two accounts range from $\$ 51$ to $\$ 136$ per net electrical kilowatt, except that the figure for Piqua is higher. For conventional plants, these costs vary from about $\$ 35$ to $\$ 100$ in the Electrical World survey and from $\$ 61$ to $\$ 87$ for single units estimated in report SL-1564.

For most nuclear plants of current design, the temperature and pressure of the steam produced are lower than for new conventional plants, the thermal efficiencies are lower, and consequently the cost per kilowatt for turbine-generators and related equipment is higher. Another reason for higher initial costs in some cases is the installation of a turbine-generator having excess capacity to take advantage of expected increases in the reactor output in the future. For example, the anticipated increase in power from 91 to 143 net Mw(e) for the Fermi plant would result in a decrease from $\$ 90$ to $\$ 57$ per kilowatt in the cost of the turbogenerator unit and accessory equipment. Other such cases are the Yankee, Big Rock Point, and Hallam plants.

\section{Miscellaneous Power Plant Equipment}

The cost of miscellaneous power plant equipment (FPC Account 325) covers such items as cranes and hoisting equipment; compressed air and cleaning systems; furniture; communication, fire extinguishing, and station maintenance equipment; laboratory, test, and weather instruments; and service water treatment systems. The figures reported for nuclear power plants seem to vary as to whether some items are included here or in other cost categories. For the plants listed in Table 3, the costs per net electrical kilowatt range from $\$ 1.50$ to $\$ 29$, except for a higher figure for Piqua. For conventional plants, these costs range from about $\$ 0.40$ to $\$ 3$ (except for four cases from $\$ 7$ to $\$ 16$ ) in the Electrical World survey and from about $\$ 1.50$ to $\$ 5$ in report SL -1564 .

\section{Interest During Construction}

Interest on funds provided by a utility during construction of a power plant is usually included in the cost of construction. However, the figures reported for nuclear plants in Table 3 are incomplete in this regard. Some utilities have not reported interest figures, while others have. Five privately-owned utilities have stated the interest rates used, which range from 5 to 6 per cent per annum. Lower interest rates usually apply to publicly-owned utilities financed by the Rural Electrification Administration (REA), municipalities, or public utility districts. No interest during construction is shown in Table 3 for funds provided by the AEC.

The figures given in Table 3 for interest during construction of nuclear plants range from $\$ 6.50$ to $\$ 59$ per net electrical kilowatt, except for a higher figure for the Carolinas-Virginia plant. Corresponding figures are not shown separately for conventional plants in the Electrical World survey; values of about $\$ 8$ to $\$ 11$ may be deduced from report SL-1564 together with report SL-1674.* However, the fact that construction costs are higher and construction periods are longer for nuclear plants means that interest during construction is also higher than for conventional plants of the same capacity.

\section{Additional Indirect Construction Costs}

There are many items prior to and during construction, in addition to interest during construction, that should be included in indirect construction costs. Among these are costs of de-

* Power Cost Normalization Studies, Civilian Power Reactor Program, Sargent and Lundy, Chicago, Sept. 1, 1959. 


\begin{tabular}{|c|c|c|c|c|c|}
\hline Plant & Status & $\begin{array}{l}\text { Year of } \\
\text { initial } \\
\text { operation }\end{array}$ & $\begin{array}{l}\text { Capacity } \\
\text { in net } \\
\text { electrical } \\
\text { megawatts }\end{array}$ & $\begin{array}{l}\text { Reported } \\
\text { total cost } \\
\text { in millions } \\
\text { of dollars }\end{array}$ & $\begin{array}{l}\text { Cost in } \\
\text { dollars per } \\
\text { net electri- } \\
\text { cal kilowatt }\end{array}$ \\
\hline \multicolumn{6}{|l|}{ Pressurized water } \\
\hline McMurdo Sound $^{2}$ & Planned & 1962 & 1.5 & 5.6 & 3730 \\
\hline$S M-1$ & Operable & 1957 & 1.9 & 3.9 & 2050 \\
\hline Saxton $^{\mathrm{b}}$ & Being built & 1962 & 3.25 & & \\
\hline APS- $1{(\text { USSR })^{c}}^{c}$ & Operable & 1954 & 5 & & \\
\hline BR-3 (Belgium) & Operable & 1960 & 10.7 & 10.3 & 960 \\
\hline Shippingport ${ }^{d}$ & Operable & 1957 & 60 & 72.9 & 1220 \\
\hline Yankee & Being built & 1960 & $110-136$ & 52.0 & $470-380$ \\
\hline SELNI (Italy) & Being built & 1963 & 176 & 56.4 & 320 \\
\hline Voronezh (USSR) & Being built & 1961 & $196 \times$ & & \\
\hline Indian Point ${ }^{e}$ & Being built & 1961 & 255 & 89.5 & 350 \\
\hline \multicolumn{6}{|l|}{ Boiling water } \\
\hline EBWR ${ }^{f}$ & Operable & 1956 & 4.5 & 4.6 & 1020 \\
\hline Vallecitos 8 & Operable & 1957 & 5 & 3.1 & 620 \\
\hline JPDR (Japan) & Planned & 1963 & 11.7 & 9.7 & 830 \\
\hline Kah1 (W. Germany) ${ }^{\mathrm{h}}$ & Being built & 1960 & 15 & 8.3 & 550 \\
\hline BONUS $^{i_{s} j}$ & Being built & 1962 & 16.3 & 12.1 & 740 \\
\hline Elk Riverk & Being built & 1961 & 22 & 12.2 & 550 \\
\hline Humboldt Bay & Planned & 1962 & 48.5 & 20.6 & 420 \\
\hline Big Rock Point 1 & Being built & 1962 & $48.5-72.8$ & 26.7 & $550-370$ \\
\hline Ulyanovsk (USSR) $^{\mathrm{m}}$ & Being built & & 50 & & \\
\hline Pathfinder $^{\text {n }}$ & Being built & 1962 & 62 & 21.8 & 350 \\
\hline Byeloyarsk (USSR) & Being built & 1962 & $94 \times 1$ & & \\
\hline SENN (Italy) & Being built & 1963 & 150 & 63.2 & 420 \\
\hline Dresden $^{\circ}$ & Operable & 1960 & 180 & 51 & 280 \\
\hline \multicolumn{6}{|l|}{ Gas cooled } \\
\hline AVR (W. Germany $)^{p}$ & Being buil* & 1961 & 15 & 9.5 & 630 \\
\hline $\mathrm{EGCR}^{\mathrm{q}}$ & Being built & 1962 & 22.3 & $\$ 0.6$ & 1370 \\
\hline $\operatorname{AGR}\left(U, K_{.}\right)$ & Being built & 1961 & 27.3 & 24.6 & 900 \\
\hline Peach Bottom $^{z}$ & Planned & 1963 & 40 & 27.8 & 700 \\
\hline Floridas & Planned & 1964 & 50.5 & 28.6 & 570 \\
\hline EDF-1 (France $)^{t}$ & Being built & 1961 & 60 & 33 & 550 \\
\hline Neuglobsow (E. Ger.) & Being built & 1961 & 70 & & \\
\hline Berkeley (U.K.) & Being built & 1961 & $137.5 \times 2$ & 123 & 450 \\
\hline Bohunice $(\mathrm{Czech} .)^{\mathrm{m}}$ & Being built & 1961 & 150 & & \\
\hline Bradwell (U.K.) & Being buxlt & 1961 & $150 \times 2$ & 134 & 450 \\
\hline Hunterston (U.K.) & Being brialt & 1962 & $150 \times 2$ & 115 & 380 \\
\hline JAPC (Japan) & Being built & 1964 & 158 & 85.6 & 540 \\
\hline EDF-2 (France $)^{v}$ & Being built & 1962 & 170 & 59 & 350 \\
\hline Latina (Italy) & Being built & 1962 & 200 & 73 & 370 \\
\hline Hinkley Point (U.K.) & Being built & 1962 & $250 \times 2$ & 186 & 370 \\
\hline Trawsfynydd (U.K.) & Being built & 1963 & $250 \times 2$ & 172 & 340 \\
\hline Dungeness (U.K.) & Planned & 1965 & $275 \times 2$ & 169 & 310 \\
\hline Sizewell (U.K.) ${ }^{y}$ & Planned & 1966 & $290 \times 2$ & 154 & 270 \\
\hline EDF-3 (France) & Planned & 1964 & 300 & 104 & 350 \\
\hline \multicolumn{6}{|l|}{ Heavy water cooled } \\
\hline Carolinas-Virginiaw $^{\text {w }}$ & Planned & 1962 & 17 & 17.7 & 1040 \\
\hline NPD-2 (Canada) & Being built & 1961 & 20 & 30.3 & 1520 \\
\hline CANDU (Canada) & Planned & 1964 & 200 & 81.5 & 410 \\
\hline \multicolumn{6}{|l|}{ Organic } \\
\hline Piqua $x$ & Being built & 1961 & 11.4 & 11.8 & 1040 \\
\hline
\end{tabular}


Table $4-$ (Continued)

\begin{tabular}{|c|c|c|c|c|c|}
\hline Plant & Status & $\begin{array}{l}\text { Year of } \\
\text { initial } \\
\text { operation }\end{array}$ & $\begin{array}{l}\text { Capacity } \\
\text { in net } \\
\text { electrical } \\
\text { megawatts }\end{array}$ & $\begin{array}{l}\text { Reported } \\
\text { total cost } \\
\text { in millions } \\
\text { of dollars }\end{array}$ & $\begin{array}{c}\text { Cost in } \\
\text { dollars per } \\
\text { net electri- } \\
\text { cal kilowatt }\end{array}$ \\
\hline \multicolumn{6}{|l|}{ Sodium graphite } \\
\hline SRE & Operable & 1958 & 5.7 & 8.6 & 1510 \\
\hline Ulyanovsk (USSR) $)^{\mathrm{m}}$ & Planned & & 50 & & \\
\hline Hallam & Being built & 1962 & $75-87$ & 45 & $600-520$ \\
\hline \multicolumn{6}{|l|}{ Fast breeder } \\
\hline Dounreay (U.K.) & Operable & 1959 & 12 & & \\
\hline EBR-II & Being built & 29621761 & 17.4 & 25.3 & 1450 \\
\hline BN-50 (USSR) & Planned & & 50 & & \\
\hline Fermi & Being built & 1961 & $91-143$ & 56.3 & $620-390$ \\
\hline
\end{tabular}

${ }^{2}$ Cost given includes shipping the unit to Antarctica and erection there.

${ }^{b}$ Contract price of $\$ 6.25$ million includes cost of fuel for five-year period of operation, but does not include cost of land, turbogenerator unit, or other pre-existing facilities.

G Graphite moderated.

${ }^{\mathrm{d}}$ Present plans for core 2 are to increase gross capacity of plant to $100 \mathrm{Mw}$ (e) (limit of existing turbine-generator) and, in addition, absorb the thermal equivalent of $50 \mathrm{Mw}(\mathrm{e})$ in a heat sink, at a cost of about $\$ 9$ million for plant modifications and the heat sink.

Superheating with oil contributes 104 of the net $255 \mathrm{Mw}(\mathrm{e})$.

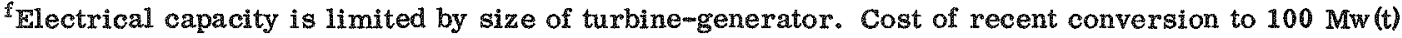
is not included.

Incremental cost at Vallecitos Atomic Laboratory, not including cost of recent modifications. Cost includes fabrication of first core. Electrical capacity is limited by size of turbine-generator.

${ }^{h}$ Cost given includes training of operating personnel and $\$ 0.2$ million already spent for planned plant extension to $30 \mathrm{Mw}(e)$, but does not include site purchase and preparation or interest during construction.

${ }^{i}$ Nuclear superheat contributes 13 to $50 \mathrm{Mw}$ (t).

${ }^{3}$ Total costs used here for BONUS, Humboldt Bay, and Hallam are the recent estimates given in footnotes of Table 2.

${ }^{k}$ Superheating with coal contributes about 7 of the 22 net Mw (e).

${ }^{1}$ Net capacity has been estimated for purposes of this report at 97 per cent of gross capacity.

mTe number of electrical megawatts given probably represents gross rather than net capacity of the plant.

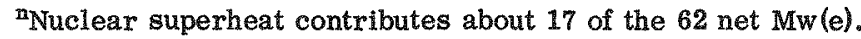

${ }^{\circ}$ Cost given includes contract price of $\$ 45$ million, cost of land at $\$ 0.55$ million, and overhead and interest during construction at $\$ 5.6$ million.

${ }^{\mathrm{P}}$ Cost given includes fabrication of first core.

ac

'Graphite-clad fuel elements.

${ }^{5}$ Cost does not include heavy-water inventory.

tUp to 68 net $\mathrm{Mw}(\mathrm{e})$ has been reported.

weavy-water moderated. The number of electrical megawatts given probably represents gross rather than net capacity of the plant.

"Up to 198 net Mw(e) has been reported.

" Cost given does not incluge heavy-water inventory or pre-existing turbine-generator. Superheating with oil contributes 10 of the $\mathrm{Mw}(\mathrm{t})$.

${ }^{x}$ Cost includes turbogenerator unit rated at $33 \mathrm{Mw}(\mathrm{e})$ and complete structure for an additional turbogenerator unit, although the gross capacity of the plant as designed is only $12.5 \mathrm{Mw}(\mathrm{e}$ ).

YCosts given are based on information that the value of the contract with the consortium of companies building the station 18 on the order of 55 million pounds sterling. 
sign, engineering, field superintendence, inspection, accounting, purchasing, taxes, insurance, contributions, and fees. Also important are costs of operating the power plant during an initial test period, minus any revenues received from plant operation during that period. Where start-up costs are known, they have been incorporated in the figures in Table 2 with footnotes indicating the amounts. Some of these indirect costs often have not been included in estimated construction costs of nuclear plants.

For the nuclear plants listed in Table 3, indirect construction costs other than interest during construction range from $\$ 14$ to $\$ 156$ per net electrical kilowatt, except for a higher figure for the Elk River plant. The Electrical World survey does not show these costs separately for conventional plants; estimates of $\$ 15$ to $\$ 30$ per killowatt can be obtained from reports SL-1564 and SL-1674 by subtracting interest during construction from total indirect costs. The higher indirect costs for nuclear plants are associated with higher direct costs and with less standardization of design, less construction experience, and less start-up experience than for conventional plants.

\section{Contingencies and Escalation}

Allowances for contingencies and escalation in estimated costs do not appear as such in final costs but are charged, if they materialize, to the applicable cost categories. Even in the case of estimates, these allowances are sometimes not shown as separate items. Where data are available, they have been included in Tables 2 and 3 . These figures are not comparable among different plants since they vary with the stage of equipment procurement and construction and approach zero as the plant nears completion. Studies and estimates often show contingencies as 10 per cent and escalation as 10 per cent of the total direct and indirect costs, excluding interest during construction and sometimes other items, such as cost of land and overhead.

The amount allowed for contingencies in cost estimates depends in part on the extent to which new technology is incorporated in the plant design. Some allowance is needed even for proven designs to cover possible delays due to emergencies, such as strikes, adverse weather, and accidents. Under fixed price contracts, a contingency allowance is made by the contractor and included in his quotation, although there may still be provisions to protect him against certain contingencies.

Estimates of escalation vary with individual forecasts of price trends and with the starting date and duration of procurement and construction. Construction costs have increased substantially during the last five years. The Handy -Whitman Electric Light and Power Construction Cost Index for U.S. steam plants increased by about 22 per cent from January 1955 to July 1959, decreased about 1 per cent by January 1960, and returned in July 1960 to the level of a year earlier. Contracts may include either an allowance for escalation in the quoted price or a provision for escalation according to a specified index.

\section{TOTAL CONSTRUCTION COSTS}

\section{Reported Costs}

Table 4 gives total construction costs of specific nuclear power plants that are operable, being built, or planned for early construction. These are arranged by reactor types and are listed in ascending order of net electrical capacity under each type. The plants considered in the preceding section are included, together with other plants for which no cost brealkdown is available.

The total figures are intended to include costs of land, structures, improvements, equipment, interest during construction, additional indirect costs, and contingencies and escalation. They are not intended to include the cost of research and development (other than that covered in a manufacturer's contract price) or the costs of training, fuel inventory, fuelelement fabrication, substation, or transmission lines. Where there are known exceptions in the reported figures, these are indicated by footnotes. No adjustments have been made to put interest during construction on a common basis or to allow for different construction costs in 
various countries. It should be emphasized that consistent cost figures are difficult to obtain and that caution is necessary in comparing the costs of different plants.

Information on several U. S. nuclear plants was not sufficiently final as of the date of this report to include them in Table 4. Examples are the Small Pressurized Water Reactor and the Improved Cycle Boiling Water Reactor to be constructed by the AEC and large nuclear power plants under consideration by the Southern California Edison Company and the Pacific Gas and Electric Company.

Also not included in Table 4 are several small nuclear plants designed to produce steam for space heating, as well as for generation of electricity. Examples are the Swedish plant, R-3/Adam, and U. S. military plants, SM-1A, SL-1, PM-1, and PM-2A. Finally, the table does not include reactors designed primarily for the production of plutonium with electricity as a by-product, such as the Calder Hall and Chapel Cross reactors in the United Kingdom and the Marcoule reactors in France.

\section{Estimates vs. Actual Costs}

Most of the nuclear power plants listed in Table 4 are still in the design or construction stage, and current estimates of costs may differ appreciably from final costs. Costs to the

Table 5-CONSTRUCTION COSTS, ESTIMATED AND ACTUAL, OF SPECIFIC NUCLEAR PLANTS

\begin{tabular}{|c|c|c|c|c|}
\hline Plant & $\begin{array}{l}\text { Original } \\
\text { estimate }\end{array}$ & $\begin{array}{l}\text { Current } \\
\text { estimate }\end{array}$ & $\begin{array}{c}\text { Actual } \\
\text { cost }\end{array}$ & $\begin{array}{c}\text { Physical construction } \\
\text { completed by } \\
\text { Sept. 30, 1960, \% }\end{array}$ \\
\hline \multicolumn{5}{|c|}{ Millions of dollars } \\
\hline EBWR $^{a}$ & 3.6 & & 4.6 & 100 \\
\hline Vallecitos ${ }^{b}$ & 3.4 & & 2.5 & 100 \\
\hline SM-1 & $1.9^{c}$ & & 3.9 & 100 \\
\hline Shippingport & 47.8 & & 72.9 & 100 \\
\hline $\mathrm{SRE}^{\mathrm{d}}$ & 3.5 & & 6.3 & 100 \\
\hline Yankee & 32.9 & 52.0 & & 100 \\
\hline Elk River ${ }^{e}$ & 6.2 & 12.8 & & 95 \\
\hline Fermi & 45.0 & 56.3 & & 95 \\
\hline Indian Point & 52.5 & $100.3^{f}$ & & 86 \\
\hline Hallam & 24.5 & $45.0^{g}$ & & 34 \\
\hline BONUS $^{h}$ & 11.0 & $11.8^{8}$ & & 1 \\
\hline
\end{tabular}

\footnotetext{
${ }^{a}$ Does not include cost of recent modifications.

bincremental cost at Vallecitos Atomic Laboratory, not including cost of recent modifications. Includes cost of first core but excludes $\$ 0.6$ million for turbine-generator.

${ }^{c_{1}}$ has been estimated that the accelerated construction schedule later adopted would have increased this to $\$ 2.1$ million.

${ }^{\mathrm{d}}$ Does not include $\$ 2.3$ million for power generating equipment and related site and structures, which the AEC did not finance.

eIncludes cost of fuel fabrication.

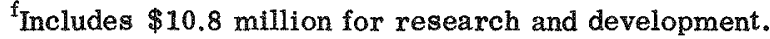

8 Based on recent estimates indicated by footnotes in Table 2.

${ }^{\mathrm{h}}$ Does not include cost of land.
}

plant owner that are fixed by contract may differ from actual expenditures by the contractor. Estimates of the construction costs of specific nuclear plants have tended to increase with time; actual costs have tended to exceed estimates. Some data on these points are given in Table 5. To compare with original estimates on a consistent basis, cost figures have been used here that may differ from those given elsewhere in this report, as indicated in the footnotes. 
There are undoubtedly many reasons for increased construction costs, and their relative importance varies from project to project. For example, in the case of the SRE, several major items of equipment, such as a metallurgical hot cell, various other experimental facilities, and storage systems for liquid waste and for dry fuel were added after the original estimate. Marked advances in technology for a sodium graphite system occurred during design and construction and were incorporated into the plant as information became available, resulting in the use of more expensive graphite, increased sodium preheat equipment, increased cooling for core shielding, etc.

The Consolidated Edison Company of New York has explained the increases from March 1955 to September 1957 in the estimated costs of its Indian Point nuclear plant as follows:

\author{
Millions
}

of dollars

$\begin{array}{lr}\text { Cost of Conventional Portion } & \\ \text { Estimate of March 1955 } & 36.5 \\ \text { Increase in gross capacity* } & 4.0 \\ \text { Escalation } & 3.5 \\ \text { Design changes } & 1.0 \\ \text { Estimate of September 1957 } & 45.0 \\ \text { Cost of Nuclear Portion } & \\ \text { Estimate of March 1955 } & 16.0 \\ \text { Increase in gross capacity* } & 2.7 \\ \text { Escalation } & 2.1 \\ \text { Waste disposal system } & 2.1 \\ \text { Safety requirements } & 3.2 \\ \text { Engineering, research, and development } & 7.4 \\ \text { Underestimate and design changes } & 6.8 \\ \text { Contingencies, overhead, and interest } & \\ \quad \text { during construction } & 4.7 \\ \text { Estimate of September 1957 } & 45.0\end{array}$

* From 236 to $275 \mathrm{Mw}(\mathrm{e})$.

The estimated total cost of construction therefore increased from $\$ 52.5$ million in March 1955 to $\$ 90$ million in September 1957 . The cost increases resulting from increased gross capacity and escalation represent situations that can also arise in the construction of fossilfuel plants. With regard to the other items, the amount of basic nuclear research and development involved was much greater than originally estimated and plans were modified a number of times, thereby increasing the cost of engineering. In addition, many items were underestimated and design changes increased the cost of the hardware, quickly eating up the original allowance for contingencies. The most recent cost estimate for the entire plant is $\$ 100.3$ million, including $\$ 10.8$ million for research and development.

\title{
Variations in Plant Cost with Design Power Level
}

The costs of nuclear power plants in dollars per net electrical kilowatt given in Table 4 are plotted against design capacity in net electrical megawatts in Fig. 1, except for the projects that cost more than $\$ 1000$ per kilowatt. Where the plant is designed for eventual operation (perhaps after the first core) at a power level higher than that expected for early operation and this is to be achieved without additional capital investment, points are shown in Fig. 1 for both situations. (There is an asterisk after the name of the plant at the point of eventual operation.) The large U. K. plants are two-unit stations. 


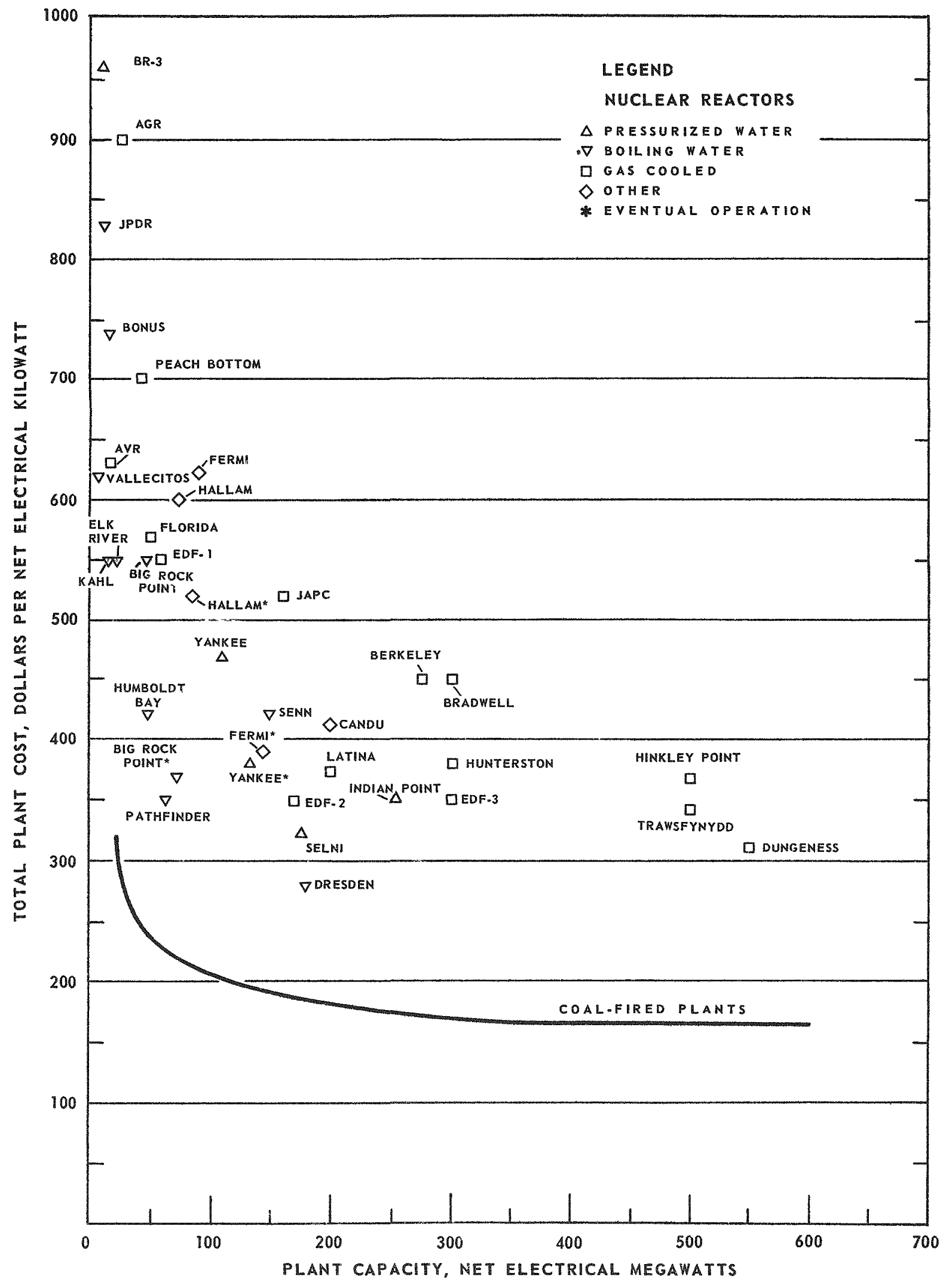

Fig. 1-Power plant costs. 
It is apparent that costs of nuclear plants in dollars per kilowatt tend to decrease as the design power level increases, although there are many fluctuations attributable to differences in design, state of technology, number of units at one site, construction costs at various locations and times, and degree of conservatism and purpose of the estimated or contract price. The limited experience with nuclear power and the changing state of technology do not permit quantitative relations to be firmly established at the present time.

For comparison, Fig. 1 also shows a cost curve for power plants burning coal. This is based on data in an engineering design study made for the AEC and published as report SL1564, which gives estimated costs for plants at an assumed location in the Middle West and at prices prevailing at the end of 1958 . The plants above $300 \mathrm{Mw}$ are two-unit stations. It is clear that construction costs are considerably higher for nuclear plants than for conventional steam plants throughout the range of capacities shown. Nuclear power could still be competitive if higher plant costs were balanced by a lower sum of costs for operation, maintenance, inventory, and fuel cycle, compared with conventional power. However, reduction in the present high costs of constructing nuclear plants is a vital objective of the development program.

\section{Effect of Surpassing the Design Power Level}

Experience with operating reactors indicates that substantial increases in power levels above the design values are often possible. The Experimental Boiling Water Reactor (EBWR) was designed to operate at a thermal power level of $20 \mathrm{Mw}$ but has achieved $60 \mathrm{Mw}$. Conversion to $100 \mathrm{Mw}(\mathrm{t})$ is scheduled for completion in September 1960 at a construction cost of $\$ 2.1$ million, which provides additional capacity for heat removal and facilities for forced circulation of coolant and use of heavy water as moderator. The Vallecitos Boiling Water Reactor was designed to operate at $20 \mathrm{Mw}(\mathrm{t})$, but has operated for extended periods at power levels up to $30 \mathrm{Mw}(\mathrm{t})$ and is licensed to operate at levels up to $50 \mathrm{Mw}(\mathrm{t})$. These increases for $\mathbb{E B W R}$ and Vallecitos are possible because the power limits set by stability requirements are considerably higher than those initially imposed on the basis of the early BORAX experiments. The limited capacity of the turbine-generator associated with each of these reactors does not permit increasing the electrical power level accordingly. Additional investment in power generating equipment could lower the over-all cost per kilowatt of electrical capacity.

The Shippingport pressurized water reactor was designed to produce sufficient heat for a capacity of 67 gross (60 net) Mw(e), but present plans for the second core are to increase the heat output to the equivalent of 150 gross $\mathrm{Mw}(\mathrm{e})$. Since the present turbine-generator has a capacity of only 100 gross $\mathrm{Mw}(\mathrm{e})$, the remainder of the energy from the reactor will be absorbed in a heat sink. The cost of the plant modifications, including the heat sink, is expected to be about $\$ 9$ million. The result will be a reduction of about 25 per cent in the plant cost per net electrical kilowatt for Shippingport. If the decision had been to install increased turbogenerator capacity of $50 \mathrm{Mw}$, there would have been a further reduction in the total plant cost per kilowatt.

Potential increases in the power level of the Dresden reactor are given on page 498 of Boiling Water Reactors, by Andrew W. Kramer, prepared for the Second International Conference on the Peaceful Uses of Atomic Energy held at Geneva in 1958. The design power level is 180 net $M w(e)$, and the construction cost based on the contract price is $\$ 51$ million or $\$ 283$ per kilowatt. The reactor and the turbine-generator may be able to operate about 5 per cent above the design level with no additional plant investment, corresponding to $190 \mathrm{Mw}$ and $\$ 268$ per kilowatt. (A level of $186 \mathrm{Mw}$ has already been attained.) The reactor core as originally designed may be capable of operating at $205 \mathrm{Mw}$, the cost of an additional turbine-generator of $15 \mathrm{Mw}$ capacity is estimated at about $\$ 1.7 \mathrm{million}$, and the over - all plant cost would then be $\$ 257$ per kilowatt.

A redesigned core, in which the diameter of the fuel elements is decreased to raise the thermal output without exceeding the central temperature limits of the fuel, may permit operation of Dresden at a power level of $245 \mathrm{Mw}$; the cost of adding to the original turbine-generator a unit of $55 \mathrm{Mw}$ capacity is estimated to be about $\$ 6$ million; and the over-all plant cost would then be $\$ 233$ per kilowatt. All the other equipment would be adequate for operation at this power level; the reactor recirculating and steam separating equipment can accommodate a 
62 per cent increase in primary steam flow without alteration. (An advanced station design of the Dresden type with a further redesign of core and increased pumping capacity and steam handling equipment might attain a level of $300 \mathrm{Mw}(\mathrm{e})$, and the plant cost per kilowatt would be further reduced.) It should be pointed out that the redesigned cores may well be more expensive to fabricate, so that a reduction in plant cost per kilowatt does not necessarily mean a reduction in the total cost of power.

\section{Thermal Efficiency}

The construction cost of a power plant per kilowatt of electrical capacity and the fuel cost per kilowatt-hour depend on the net thermal efficiency of the plant, which is defined as the ratio between the net electrical output of the plant and the thermal input from the fuel. The thermal input for a conventional boiler or superheater is measured by the heat of combustion of all the fossil fuel used and includes energy lost through the furnace walls and the smokestack. The 1959 survey of modern steam plants by the Electrical World gives losses averaging 14 per cent of the heat content of the fuel fired. In the case of nuclear plants, the thermal input is usually not calculated from the fuel consumed but from the increase in energy content of the coolant in passing through the reactor. This should (but may not always) include any heat removed in cooling the shielding and the moderator even if this energy is lost from the steam-generating system. These losses are estimated to be 0.5 per cent of the heat generated in the Dresden reactor, 3.5 per cent for EBR-II (primarily in cooling the shield of this small, compact reactor whose ratio of surface area to core volume is large), 9.6 per cent for the Florida reactor, and 9.5 per cent for the Carolinas-Virginia reactor (primarily in cooling the heavy -water moderator in these two cases). Other losses, such as the decay of radioactive fission products after discharge from the reactor, may not be measured or estimated but should be relatively small. To the extent that losses are not included in the calculations for nuclear reactors, thermal efficiencies of nuclear plants are somewhat overrated in comparison with conventional plants.

The net thermal efficiency depends on the design and performance of the steam-generating equipment and other equipment, the temperature and pressure of the steam passing through the turbine-generator, and the amount of electrical energy consumed in operating the plant itself. The operating efficiency may differ from the design value because of such variables as the temperature of the condenser cooling water and stand-by time when fuel is being burned but no electricity is being generated. The efficiency of the best new plants burning coal in the United States has increased from about 8 per cent in 1905 to about 29 per cent in 1935 and to about 40 per cent at present. The average for old and new plants has increased from about 5 per cent in 1905 to about 20 per cent in 1935 and to about 33 per cent at present. These advances have resulted from increasing boiler efficiencies and turbine internal efficiencies, using reheat and regenerative feedwater heating, reducing turbine exhaust pressures, minimizing make-up requirements for feedwater flow, reducing mechanical, hydraulic, and electrical losses in plant equipment, and especially from utilizing steam at the higher temperatures and pressures made possible by improvements in the properties of materials.

The technology of conventional plants is also available for nuclear plants, but cannot be fully utilized at present because of additional requirements that must be met. The necessity of conserving neutrons, protecting the nuclear fuel while it is being burned, and confining the fission products means that structural, cladding, and alloying materials have to be developed not only to withstand thermal and corrosive effects but also to perform well under neutron irradiation. The result is that nuclear plants are not now operating at the steam temperatures and pressures common for conventional plants, which are 950 to $1050^{\circ} \mathrm{F}$ and 1250 to $3500 \mathrm{psi}$. However, efforts are being made to improve nuclear plants in this regard. One method is to use gaseous coolants or liquid coolants with high boiling points. (The difference between gross and net thermal efficiency tends to be larger for gas-cooled than for liquid-cooled reactors of the same capacity, because of the greater power required in circulating the gas.) Another method is to superheat the steam, either by passing it through a higher temperature portion of the reactor or by heating it with fossil fuel. 
Table 6-DESIGN VALUES OF EFFICIENCY AND STEAM CONDITIONS FOR SPECIFIC NUCLEAR POWER PLANTS

\begin{tabular}{|c|c|c|c|}
\hline \multirow[b]{2}{*}{ Plant } & \multirow{2}{*}{$\begin{array}{l}\text { Net thermal } \\
\text { efficiency, \% }\end{array}$} & \multicolumn{2}{|c|}{$\begin{array}{l}\text { Steam conditions at outlet } \\
\text { of nuclear steam generator }\end{array}$} \\
\hline & & Temp., ${ }^{\circ} \mathrm{F}$ & Pressure, psia \\
\hline \multicolumn{4}{|l|}{ Pressurized water } \\
\hline McMurdo Sound & 14.4 & 417 & 300 \\
\hline SM-1 & 17.9 & 425 & 213 \\
\hline Saxton & 16.2 & & $300-500$ \\
\hline APS-1 (USSR) ${ }^{\mathrm{b}}$ & 16.7 & 536 & 178 \\
\hline BR-3 (Belgium) & 24.9 & 471 & 520 \\
\hline Shippingport & 26.0 & 486 & 600 \\
\hline Yankee & 28.0 & 467 & 500 \\
\hline SELNI (Italy) & 28.6 & 467 & 515 \\
\hline Voronezh (USSR) & 25.8 & 446 & 470 \\
\hline Indian Point ${ }^{c}$ & 25.8 & 449 & 420 \\
\hline \multicolumn{4}{|l|}{ Boiling water } \\
\hline EBWR & 22.5 & 489 & 615 \\
\hline Vallecitos & 25.0 & 545 & 1000 \\
\hline JPDR (Japan) & 29.2 & 529 & 877 \\
\hline Kahl (W. Germany) & 25.0 & 497 & 663 \\
\hline BONUS ${ }^{d}$ & 32.6 & 900 & 865 \\
\hline Elk River ${ }^{e}$ & 26.0 & 505 & 700 \\
\hline Humboldt Bay & 29.8 & 548 & 1025 \\
\hline Big Rock Point & 31.1 & 546 & 1015 \\
\hline Ulyanovsk (USSR) & 20.0 & 446 & 426 \\
\hline Pathfinder 8 & 30.5 & 825 & 555 \\
\hline Byeloyarsk (USSR) $^{\mathrm{h}}$ & 33.0 & 950 & 1470 \\
\hline SENN (Italy) & 29.5 & $543 / 469$ & $990 / 510$ \\
\hline Dresden & 28.7 & $543 / 469$ & $990 / 510$ \\
\hline \multicolumn{4}{|l|}{ Gas cooled } \\
\hline AVR (W. Germany) $)^{b}$ & & 941 & 1045 \\
\hline EGCR & 26.5 & 900 & 1325 \\
\hline AGR (U.K.) & 27.3 & 860 & 675 \\
\hline Peach Bottom & 34.8 & 1005 & 1500 \\
\hline Florida ${ }^{i}$ & 32.6 & 950 & 1465 \\
\hline EDF-1 (France) & 20.0 & $649 / 421$ & $309 / 63$ \\
\hline Neuglobsow (E. Ger.) ${ }^{j}$ & 28.0 & 454 & 426 \\
\hline Berkeley (U.K.) & 24.4 & $612 / 612$ & $321 / 77$ \\
\hline Bohunice $(\mathrm{Czech} .)^{f}$ & 25.4 & $752 / 356$ & $426 / 29$ \\
\hline Bradwell (U.K.) & 28.2 & $703 / 703$ & $770 / 210$ \\
\hline Hunterston (U.K.) & 28.0 & $700 / 660$ & $595 / 165$ \\
\hline JAPC (Japan) & 27.7 & $714 / 687$ & $910 / 285$ \\
\hline EDF-2 (France) & 25.0 & $644 / 644$ & $473 / 126$ \\
\hline Latina (Italy) & 28.4 & $703 / 703$ & $770 / 210$ \\
\hline Hinkley Point (U.K.) & 26.4 & $685 / 669$ & $665 / 195$ \\
\hline Trawsfynydd (U.K.) & 28.7 & $720 / 694$ & $977 / 319$ \\
\hline Dungeness (U.K.) & 32.9 & $739 / 743$ & $1418 / 590$ \\
\hline Sizewell (U.K.) & 30.5 & $736 / 734$ & $720 / 305$ \\
\hline EDF-3 (France) & & & \\
\hline \multicolumn{4}{|l|}{ Heavy water cooled } \\
\hline Carolinas-Virginiak & & 487 & 605 \\
\hline NPD-2 (Canada) & 24.2 & 448 & 415 \\
\hline CANDU (Canada) & 29.1 & 482 & 580 \\
\hline \multicolumn{4}{|l|}{ Organic } \\
\hline Piqua & 25.1 & 550 & 450 \\
\hline \multicolumn{4}{|l|}{ Sodium graphite } \\
\hline $\operatorname{SRE}^{1}$ & 27.0 & 825 & 615 \\
\hline Ulyanovsk (USSR) & & 932 & 1320 \\
\hline Hallam & 29.5 & 833 & 865 \\
\hline
\end{tabular}


Table $6-$ (Continued)

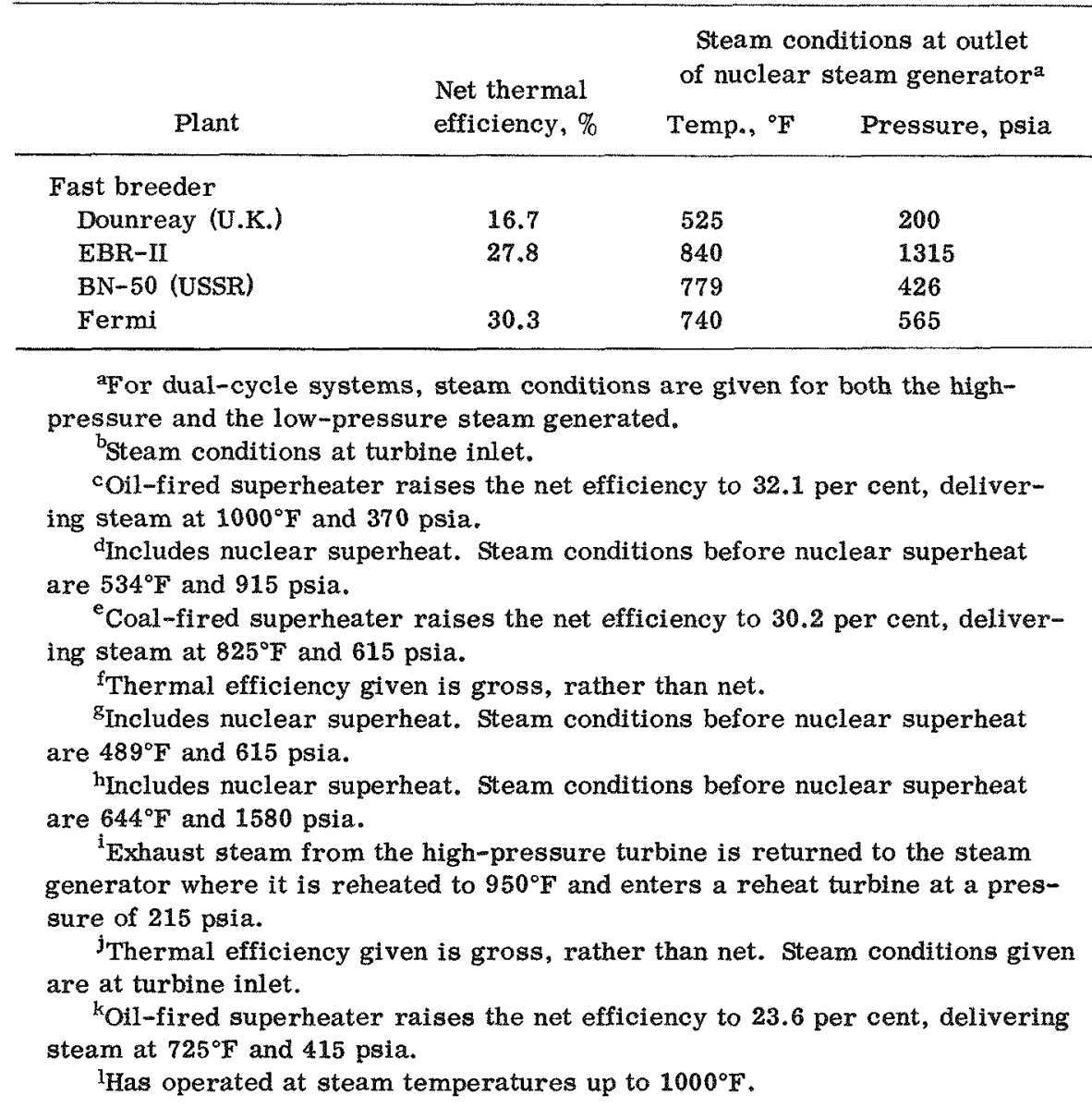

Design values of net thermal efficiencies and steam conditions for nuclear plants are listed in Table 6. Where there is a fossil-fuel superheater, its effect is not included in the table but is given in a footnote. The efficiencies range from about 24 to 35 per cent, the temperatures from 450 to $1000^{\circ} \mathrm{F}$, and the pressures from 300 to $1500 \mathrm{psi}$, except that the figures are lower for a few of the small plants.

\section{Variations in Plant Cost with Reactor Type}

Each type of reactor now being seriously studied has potential advantages and disadvantages compared with other types. Some of these, such as safety, cannot be evaluated by the estimated cost of nuclear power. Furthermore, plant costs are only one item, although an important one, in the total cost of nuclear power; lower plant costs may be offset by higher fuel or operating costs. Although knowledge and experience to date do not enable firm, quantitative statements to be made, the following discussion indicates in a qualitative way some factors believed to be important in determining relative capital costs.

Water cooled and moderated reactors can draw on a large amount of engineering and operating experience with equipment handling water and steam over a wide range of temperatures and pressures. Pressurized light-water reactors are known to be feasible as the result of operating a number of units, both civilian and military, and much of this experience is directly applicable to pressurized heavy-water reactors as well. The good heat-removal characteristics of liquid water permits the attainment of high power densities. However, existing nuclear plants using pressurized-water reactors produce steam of substantially lower pressures and temperatures and have lower thermal efficiencies and higher turbine costs than do conven- 
tional thermal plants of modern design. Higher pressures would increase the costs of the pressure vessel and associated equipment. Moreover, fabrication and transportation problems limit the size and the maximum power level of a practical pressure vessel. The temperature of the steam and the thermal efficiency of plants utilizing pressurized-water reactors can be increased by nuclear or fossil-fuel superheating. The Consolidated Edison and CarolinasVirginia plants will use oil-fired superheaters for this purpose.

Heavy water provides considerably better neutron economy than light water. However, the volume of moderator required is greater for heavy water than for light water, so that the size of the reactor is increased. Limitations on the practical size of pressure vessels can be avoided by the use of pressure-tube designs, which will be tried in the Carolinas-Virginia and the Canadian NPD-2 and CANDU reactors. Precautions taken to reduce losses of heavy water during operation tend to increase plant construction costs. Furthermore, the value of the heavy-water inventory is a substantial item.

Boiling-water reactors using light water have been demonstrated in sizes up to 180 net Mw(e). They have the advantage of operating at much lower coolant pressures than pressurized-water reactors while producing steam of the same or higher temperature. The high heat-transfer rate obtainable under conditions of nucleate boiling may permit high specific power, thus reducing the in-reactor inventory of fissionable material. For certain designs the presence of vapor bubbles may serve as an automatic safety feature in that loss of coolant supply reduces reactivity. For boiling-water reactors in sizes up to $100 \mathrm{Mw}(\mathrm{e})$, designs using natural circulation appear to be feasible and to have economic advantages because of reduced costs of equipment. In larger sizes, all current designs require forced cir culation. The elimination of the steam generator between the reactor and the turbine reduces construction costs, but may place a more severe requirement on fuel-element integrity to prevent radioactive contamination of the turbine by steam flowing directly from the reactor. Boiling-water reactors appear to be more readily adaptable than pressurized-water reactors to nuclear superheating. The Northern States and BONUS plants will provide for nuclear superheating by recirculating the steam through the reactor. The Elk River plant will use a coalfired superheater.

Organic-cooled reactors may operate at coolant pressures of one-eighth to one-tenth of those for boiling-water reactors, while producing steam at the turbine of about the same temperature and quality. The radioactivity induced in the coolant is low. Ordinary steel and some items of conventional equipment have been used in the Organic Moderated Reactor Experiment. However, there has been some fouling of fuel elements and other heat-transfer surfaces. The heat-transfer properties of organic materials are inferior to those of water, so that the heat exchangers must be larger than for water reactors. The specific power and the power density of organic reactors are lower than for light-water reactors, resulting in larger fuel inventories and larger reactor cores. The lower cost of structural materials and equipment may more than balance the higher cost resulting from the greater size of the core, compared with water reactors. Additional considerations enter into the total cost of electricity, such as the cost of make-up of the oxganic material on the one hand and the savings in the cost of fuel-element fabrication on the other hand.

Sodium-cooled reactors operating at relatively low coolant pressures can generate steam of temperature and quality comparable with the steam conditions in modern fossil-fuel plants. Heat-removal characteristics of sodium are excellent, permitting high specific powers. Special attention must be paid to the chemical reactivity of sodium and its high induced radioactivity. Sodium must be kept free of oxygen to prevent severe corrosion. Although many cheap structural materials are resistant to corrosion by sodium, the present lack of large-scale commercial experience with sodium as a coolant means that development costs for special equipment will result in increased manufacturing costs. Sodium is not readily compatible with good moderators. Use of graphite may require that it be canned to prevent absorption of sodium, and use of heavy water poses problems of chemical incompatibility.

The principal advantage of the sodium-cooled fast-breeder reactor is the high breeding gain possible. The high power density of the core of a fast breeder requires the use of a coolant with the excellent heat-removal properties of sodium. The other advantages and disad- 
vantages of sodium as a coolant in such a reactor are the same as discussed above, except that there is no moderator to pose compatibility problems.

Gas-cooled reactors, operating at coolant pressures of one-half to one-fourth of those for boiling-water reactors, may permit the generation of superheat steam comparable to that for modern fossil-fuel plants. Such reactors can be designed to operate on natural uranium; the reactivity limit on fuel life may then be a problem if the moderator is graphite but will be less serious if the moderator is heavy water. Gas-cooled reactors fueled with natural uranium tend to have large, and consequently expensive, reactor vessels and heat exchangers. The reactor vessels are particularly large if graphite is used as the moderator; pressure-tube reactors moderated with heavy water are smaller. Power densities are increased and reactor size reduced in designs utilizing enriched uranium as fuel. Gas-cooled graphite-moderated reactors can be designed so that their reactivity decreases markedly with increasing temperature, thus providing a very important safety factor.

\section{WORKING CAPITAL}

Working capital is defined as current assets minus current liabilities. In computing working capital, consideration should be given to such assets as cash, temporary cash investments, accounts receivable, prepayments, and materials and supplies, and to such liabilities as accounts payable, customers' deposits, taxes accrued, and interest accrued.

For fossil-fuel plants in the United States, the average working capital is small compared with the plant investment. The principal item in materials and supplies for fossil-fuel plants is the stocks of coal or oil. Current practice of utilities is to maintain stocks sufficient for approximately 110 days of normal operation. For typical plants, this amounts to $\$ 3$ to $\$ 4$ per electrical kilowatt.

For a nuclear plant, the fuel inventory includes material in various stages of chemical conversion and fabrication into fuel elements, shipment to and storage at the reactor site, irradiation in the reactor, cooling after discharge, shipment to and storage at the chemical processing site, and chemical recovery and conversion. If special nuclear material is leased to the utility, as it is now within the United States, the value of that material is not included by the utility in the amount for materials and supplies. However, the cost of fabricating the material into fuel elements is initially charged to that account and is then gradually transferred to operating expenses during irradiation.

The fabrication value is zero when the fuel elements are finally discharged from the reactor. If it is assumed that the decrease in value is linear with time during irradiation, the average fabrication value for fuel elements in the reactor is one-half of their fabrication cost. The account for materials and supplies should also include payments made by the utility for replacement fuel elements in production or waiting to go in the reactor and for spare fuel elements. Calculations of average investment in fabrication of fuel elements for several specific reactors give results ranging from about $\$ 15$ to $\$ 35$ per net electrical kilowatt of installed capacity, except for a higher figure for the Carolinas-Virginia plant. This is much

larger than the typical investment of $\$ 3$ to $\$ 4$ per kilowatt in fuel stocks for a fossil-fuel plant.

If special nuclear material were sold to the utility, the value of this material in the inventory would also be included in working capital. This inventory depends on characteristics of the fuel cycle for the particular reactor, including fabrication, irradiation, cooling, and processing times. Calculations for several power reactors indicate values of the uranium inventory ranging from $\$ 40$ to $\$ 200$ per net electrical kilowatt of installed capacity, except for a higher figure for the Fermi plant.

\section{ANNUAL FIXED CHARGES}

This section discusses the annual fixed charges on capital invested in power plants in the United States. These charges include the cost of money, depreciation, interim replacements, insurance, and taxes and are expressed as percentages to be applied against initial investment. 
To obtain the contribution of annual fixed charges to the cost of power in mills per kilowatthour, consideration is given to the plant factor which, together with the power capacity, determines the kilowatt-hours generated per year.

This report applies the same methods of computing annual fixed charges to nuclear plants as to fossil-fuel plants, so that comparisons can be made of the total costs of generating electricity. Expressed as percentages of plant investment, the same rates of return and tax rates, but greater depreciation and insurance rates, are assumed for nuclear plants compared with estimated averages for fossil-fuel plants. Separate consideration is given to utilities owned by private companies, by municipalities, and by cooperatives. These computations presuppose normal financing of nuclear plants for each type of utility and allowance of the full amount of annual fixed charges in the rate structure. The actual situation for a utility system containing a nuclear plant will depend on the method of financing the plant and on decisions to be made by rate-making bodies with regard to costs in excess of those for a comparable fossil-fuel plant.

\section{Cost of Money}

Average private financing of fossil-fuel power plants is approximately 50 per cent bonds, 15 per cent preferred stocks, and 35 per cent common stocks. Annual rates of return have been estimated in Technical Memorandum No. 1 and its supplements and revisions issued by the Bureau of Power (FPC). These estimates for the last three years are:

\begin{tabular}{lcccc} 
& \multicolumn{5}{c}{ Annual rates of return, \% } \\
& Bonds & $\begin{array}{c}\text { Preferred } \\
\text { stocks }\end{array}$ & $\begin{array}{c}\text { Common } \\
\text { stocks }\end{array}$ & $\begin{array}{c}\text { Weighted } \\
\text { average }\end{array}$ \\
Jan. 1, 1958 & 4.00 & 4.635 & 9.443 & 6.00 \\
Jan. 1, 1959 & 4.50 & 5.00 & 9.57 & 6.35 \\
Jan. 1, 1960 & 5.00 & 5.50 & 9.79 & 6.75
\end{tabular}

Since early in 1960, the trend in bond interest has been downward.

Power plants owned by municipalities, public utility districts, and rural cooperatives are financed by money costing less than for privately-owned plants. For example, plants owned by municipalities are financed largely by bonds, and Moody's Municipal Bond Yield Composite Average for 1959 and also for June 1960 was 3.74 per cent per annum. For September 1960, this figure was 3.55 per cent. Power plants have been financed by the REA by loans bearing interest of 2 per cent per annum.

\section{Depreciation}

In making economic analyses of power projects, the Bureau of Power (FPC) uses an esti mated service life of 35 years for fossil-fuel plants of modern design. We are taking a shorter period of 30 years for nuclear plants to make some allowance for special features of these plants, such as irradiation effects.

The annual fixed charge for depreciation depends on the method used. By the method of straight-line depreciation used by most of the privately-owned utilities, equal allowances are made for depreciation each year and the undepreciated balance for a particular plant decreases correspondingly year by year. The annual return on the investment is figured on the balance after deduction of the accumulated depreciation. The depreciation allowances are often reinvested in new plants of the utility.

By the sinking-fund method, frequently used in evaluation studies, the return each year is figured on the initial plant investment. The annual depreciation is taken as the annual amount of money that, if reinvested, would accumulate to the initial plant investment at the end of the depreciation period. The rate of return on the reinvested money is assumed to equal the weighted average rate of return on the utility's bonds and stocks. The sinking-fund method is used in this report because of its convenience and because it gives the same sum for depreciation plus return as the average for the straight-line method if account is taken of the present value of future payments. 
Land and heavy water are nondepreciable items and their costs should be subtracted from total construction costs before figuring depreciation. The effect is small in the case of land but can be important in the case of heavy water.

\section{Interim Replacements}

Provision must be made for replacing items of equipment having a life span less than the estimated service life of the plant. With the sinking-fund method of depreciation, the Bureau of Power (FPC) uses an average allowance for interim replacements equal to 0.35 per cent of the plant investment for fossil-fuel plants, and the same allowance is assumed here for nuclear plants. However, modification of this figure may be necessary when substantial experience with commercial nuclear power plants becomes available.

\section{Insurance}

The annual insurance cost for a conventional thermal plant ranges from 0.10 to 0.35 per cent of the total plant investment. An average of 0.25 per cent is used by the Bureau of Power (FPC). For a nuclear plant, property insurance will probably be increased by the nuclear hazards to the plant itself and may perhaps be doubled, ranging from 0.2 to 0.7 per cent of the total plant investment.

In addition, the law requires that private operators of nuclear plants having a capacity over $100 \mathrm{Mw}(e)$ purchase the full amount of liability insurance available from commercial sources, which is presently $\$ 60,000,000$. The cost of this insurance depends on the location, safety characteristics, and thermal capacity of the nuclear plant. Actual or estimated annual premiums for several plants, when converted to percentages of plant investment, range from 0.2 to 0.7 per cent. Finally, the fee for indemnity up to $\$ 500,000,000$ provided by the Federal Government for nuclear plants is $\$ 30$ per year per thermal megawatt. This fee amounts to an annual rate of about 0.03 per cent of the plant investment at $\$ 350$ per installed electrical kilowatt, and lower percentages for higher unit investments. The annual cost of liability insurance and indemnity together may therefore vary from 0.23 to 0.73 per cent of the plant investment.

The total insurance cost for a nuclear plant, expressed as a percentage of plant investment, may thus range from 0.43 to 1.43 per cent, and an intermediate value of 0.8 per cent is adopted here.

\section{Taxes}

State and local taxes paid by privately-owned utilities generally include property, income, franchise, capital stock, gross earnings or receipts, occupation or license, energy or generation, unemployment, and excise taxes. The Bureau of Power (FPC) has found the national average to be 2.35 per cent of plant investment. Approximately 66 per cent of the total of state and local taxes is property or ad valorem taxes. Federal taxes other than income include oldage, unemployment, and excise taxes and amount annually to about 0.1 per cent of the investment in privately-owned power plants.

For Federal income tax, the normal and surtax corporate rate amounts to 52 per cent of the difference remaining after deduction from gross revenues of other taxes, all production costs (including those for operation, maintenance, and fuel), depreciation, insurance, and interest to bondholders. The Federal Revenue Act of 1954 permits the use of liberalized depreciation methods for income-tax purposes with regard to depreciable plant investment made after Dec. 31, 1953. Many privately-owned utilities have adopted such methods, with the result that part of their annual income tax is deferred during the first portion of the depreciation period. Even when tax deferrals are added to the taxes paid, there are large variations in annual Federal income taxes from one company to another, the range being from 2 to 6 per cent of the plant investment except in a few cases. The Bureau of Power (FPC) has found the national average to be 3.40 per cent and that figure is used here.

Our treatment of income taxes assumes that all the costs of nuclear power will be included in the rate structure and passed on to the consumers of electricity. Where this is not the case, 
installation of a nuclear plant rather than a conventional plant may reduce the taxable corporate income and the income taxes paid.

For publicly-owned power plants, there are no Federal income taxes. It is estimated that direct taxes and payments in lieu of taxes to State and local governments amount to about 1.4 per cent of plant investment for municipally-owned utilities and 0.8 per cent for utilities owned by rural cooperatives. In addition, municipal plants may provide electricity without charge to the city for such purposes as street lighting.

\section{Total Annual Fixed Charges on Plant Investment}

Representative figures for annual fixed charges as percentages of plant investment are summarized and totaled in Table 7. Where these charges are different for nuclear than for

Table 7-ANNUAL FIXED CHARGES AS PERCENTAGE OF PLANT INVESTMENT

\begin{tabular}{llll}
\hline & $\begin{array}{c}\text { Private } \\
\text { company }\end{array}$ & Municipality & $\begin{array}{c}\text { Cooperative } \\
\text { financed } \\
\text { by REA }\end{array}$ \\
\hline Cost of money & 6.75 & 3.74 & 2.00 \\
Depreciation & $1.11(0.77)$ & $1.86(1.43)$ & $2.46(2.0)$ \\
Interim replacements & 0.35 & 0.35 & 0.35 \\
Insurance & $0.8(0.25)$ & $0.8(0.25)$ & $0.8(0.25)$ \\
Federal income taxes & 3.40 & 0 & 0 \\
Other taxes & 2.45 & 1.4 & 0.8 \\
\multicolumn{1}{c}{ Total } & $14.86(13.97)$ & $8.15(7.17)$ & $6.41(5.4)$ \\
\hline
\end{tabular}

fossil-fuel plants, the first entry is for nuclear plants and the one in parentheses is for fossilfuel plants.

\section{Total Annual Fixed Charges on Working Capital}

Working capital is not a depreciating asset and is therefore not subject to fixed charges for depreciation or for interim replacements. In studies of the cost of electric power, fixed charges on working capital always include the cost of money but may not include taxes and insurance. For example, in Technical Memorandum No. 1 of the Bureau of Power (FPC), fixed charges on plant investment cover all taxes and insurance, and fixed charges on capital invested in stocks of coal or oil are based only on the cost of money.

For the working capital invested in the fuel cycle of nuclear plants, figures have been quoted for annual fixed charges that are based (1) only on the cost of money or (2) on the cost of money plus Federal income taxes or (3) on the cost of money plus all taxes plus insurance. According to Table 7, the corresponding annual fixed charges for a privately-owned nuclear plant would be 6.75 or 10.15 or 13.4 per cent. This problem arises only in studies and not in the actual accounts of utilities, where taxes and insurance are costed as incurred and are not computed as percentages of plant investment or of working capital. Since the working capital required for the fuel cycle of nuclear plants is much greater than for fossil-fuel plants, it is especially important that all applicable fixed charges be included in the total cost of generating electricity and that none be duplicated, whatever method is used.

One approach is to consider the effect of changes that may occur in the capital invested in the fuel cycle of nuclear plants during their service life as a result of variations in operating conditions, core design, or fuel-element fabrication cost. Such changes would not necessarily affect the amount of liability insurance but could affect the amount of property insurance. In those states where materials and supplies of utilities are not taxed, property taxes would not be affected. If rate-making bodies allow a fixed rate of return after taxes on the investment in the fuel cycle, changes in that investment will have an effect on total returns and thus on income taxes. Fixed charges on the fuel-cycle investment may therefore be taken to include the 
cost of money, property insurance (at an approximate average rate of 0.5 per cent per year), and state and Federal income taxes (for privately-owned plants). On the basis of Table 7 , the annual fixed charges on working capital invested in the fuel cycle would then be about 11 per cent for privately-owned nuclear plants, about 4.25 per cent for municipally-owned plants, and about 2.5 per cent for cooperatives financed by the REA.

\section{Plant Factor}

To compute the contribution of annual fixed charges to the unit cost of electric energy, the number of kilowatt-hours generated by a given plant each year must be estimated. This is de$t \in$ rmined by the product of the time during which the plant is operating and the average power level during operation. When expressed as a percentage of the energy that would have been generated if the plant had operated continuously at rated capacity, this is called the plant factor.

The plant factor for a nuclear plant is determined by the technical capability of the installation, by the demand for electric energy, and by the relative operating and transmission costs of the nuclear plant and conventional plants in the same system. On the basis of considerable experience with production reactors and very limited experience with power reactors, it is often assumed that a nuclear power plant, after an initial test period, would be technically capable of attaining a plant factor of 80 per cent or more, allowance being made for scheduled and unscheduled reductions in power and shutdowns. If high irradiation levels are reached without fuel-element failures, the frequency of charging and discharging the reactor core will be much lower than for existing production reactors. Power reactors under construction in the United Kingdom, utilizing natural uranium metal as fuel and having a lower irradiation level than is expected for most United States power reactors, are designed for charging and dis charging fuel elements while the reactor is operating. The Calder Hall and Chapelcross reactors, operated for the production of plutonium and electricity, do not have that feature but, including the scheduled closures for recharging the reactors, an operating availability in excess of 80 per cent has been achieved. In the United States, the average plant factor for the Shippingport reactor, operated primarily for developmental purposes, was slightly above 30 per cent during 1958, the first year after attaining criticality; in the year ending on June 30, 1959, the plant factor was 48.9 per cent.

The demand for electric energy experienced by any utility serving the public varies with the hour of the day and the day of the year. However, there is a base load representing the minimum demand to be met at all times. For large utilities, the base load is sufficient to require the operation of several power generators, the choice depending on the relative production expenses (costs of operation, maintenance, and fuel) and transmission expenses for the units available. If the capacity of the nuclear plants in a given system is within the base load of that system, and if the production and transmission expenses are less for the nuclear plants than for the conventional plants in the system, then the nuclear plants would be operated at the highest plant factor they are technically able to achieve. Even with favorable production expenses relative to fossil-fuel plants, the average plant factor for nuclear plants will start to decrease when their total capacity begins to exceed the base load. The average plant factor for fossil-fuel plants operated by utilities in the United States was 55 per cent in 1959.

\section{Fixed Charges in Mills Per Kilowalt-hour}

Table 8 can be used to obtain fixed charges on plant and fuel-cycle investments in mills per kilowatt-hour. Annual fixed charges are taken as 15 per cent on plant investment and 11 per cent on fuel-cycle investment for privately-owned plants, 8.25 and 4.25 per cent for the respective investments in municipally -owned plants, and 6.5 and 2.5 per cent for the respective investments in cooperatives financed by the REA. For example, if the plant factor is 80 per cent, the plant investment $\$ 400$ per kilowatt, and the fuel-cycle investment (in fabrication of fuel elements) $\$ 30$ per kilowatt, then the total fixed charges are 9.0 mills per kllowatt-hour for a privately-owned plant, 4.9 for a municipally-owned plant, and 3.8 for a cooperative financed by REA. 
Table 8-FLXED CHARGES ON PLANT AND FUEL-CYCLE INVESTMENTS

(In mills per kilowatt-hour)

\begin{tabular}{|c|c|c|c|}
\hline Plant factor, $\%$ & $\begin{array}{l}\text { Private } \\
\text { company }\end{array}$ & Municipality & $\begin{array}{c}\text { Cooperative } \\
\text { financed } \\
\text { by REA }\end{array}$ \\
\hline & \multicolumn{3}{|c|}{$\begin{array}{c}\text { For each } \$ 100 \text { of plant investment } \\
\text { per net electrical kilowatt }\end{array}$} \\
\hline 40 & 4.28 & 2.35 & 1.86 \\
\hline 50 & 3.42 & 1.88 & 1.48 \\
\hline 60 & 2.85 & 1.57 & 1.24 \\
\hline 70 & 2.45 & 1.35 & 1.06 \\
\hline \multirow[t]{2}{*}{80} & 2.14 & 1.18 & 0.93 \\
\hline & \multicolumn{3}{|c|}{$\begin{array}{c}\text { For each } \$ 10 \text { of fuel-cycle investment } \\
\text { per net electrical kilowatt }\end{array}$} \\
\hline 40 & 0.31 & 0.12 & 0.071 \\
\hline 50 & 0.25 & 0.097 & 0.057 \\
\hline 60 & 0.21 & 0.081 & 0.048 \\
\hline 70 & 0.18 & 0.069 & 0.041 \\
\hline 80 & 0.16 & 0.061 & 0.036 \\
\hline
\end{tabular}

\section{FUEL-CYCLE COSTS}

This section deals with the costs of the fuel cycle for nuclear power plants. Included are the cost of fabricating the fuel elements, the cost of transporting irradiated fuel elements, the cost of chemical processing of irradiated fuel and chemical conversion of the special nuclear materials recovered, the use charge for leased fuel, the cost of fuel consumption, and the credit for plutonium and $U^{233}$ produced. (Charges on the investment in fuel-element fabrication are discussed in the previous section, and costs of operation and maintenance, including the cost of moderator and coolant make-up, are discussed in the next section.) To express fuelcycle costs in mills per kilowatt-hour of electricity generated, the irradiation level of the nuclear fuel must be considered first.

\section{Irradiation Level}

In this report, the irradiation level for normal and moderately enriched uranium is given in terms of the megawatt days of heat generated per metric ton of uranium in the reactor, abbreviated $\mathrm{Mwd} / \mathrm{mtU}$. The peak irradiation level, often occurring in the center of a reactor, may be several times greater than the average irradiation level for the reactor as a whole. Increasing the average irradiation level reduces the annual throughput of fuel and the annual cost of fabricating, shipping, and processing fuel elements of a fixed design. However, fuel elements capable of withstanding higher irradiation levels may be more expensive to fabricate and process. Moreover, the enrichment of the fuel may have to be increased to maintain reactivity, with the result that burn-up and use charges are raised. The consumption of plutonium or $\mathrm{U}^{233}$ generated in the reactor increases with the irradiation level, and the effect on fuel-cycle costs depends on the prices of these materials compared with the primary fuel, usually $\mathrm{U}^{235}$.

Plans for reactors using natural or somewhat enriched uranium are usually based on attaining average irradiation levels in the range of 3000 to $15,000 \mathrm{Mwd} / \mathrm{mtU}$. Warranties of fuelelement performance in this range are being given by manufacturers. In the joint program of the United States and Euratom for the installation of nuclear power plants in the Euratom countries, the United States is offering standard fuel-element guarantees of an irradiation level of $10,000 \mathrm{Mwd} / \mathrm{mtU}$ for uranium-oxide fuel elements meeting certain specifications.

In small-scale experiments, zirconium tubes containing enriched uranium-oxide pellets have been irradiated to $30,000 \mathrm{Mww} / \mathrm{mtU}$ without deleterious effects. However, there is cur- 
rently some concern that cracks in zircaloy tubing may become progressively worse during reactor operation, and improved alloys of zirconium are being sought. Samples of enriched uranium oxide dispersed in stainless steel and enriched uranium metal alloyed with zirconium have been irradiated to similar levels with good dimensional stability.

The irradiation level for normal uranium-oxide pellets in zirconium tubes in the Shippingport reactor has reached an average of about 3000 and a peak of about $15,000 \mathrm{Mwd} / \mathrm{mtU}$; the peak occurs near the highly enriched seed. In an experiment in the United Kingdom using one of the Calder Hall reactors, normal uranium metal slugs clad with Magnox (a magnesium alloy) had, by March 1960 , reached an average irradiation level of over $700 \mathrm{Mwd} / \mathrm{mtU}$, with a number of fuel elements achieving 2000; such fuel elements are intended to attain $3000 \mathrm{Mwd} / \mathrm{mtU}$ in $U$. K. power reactors under construction.

With regard to enriched uranium, the first core in the EBWR with plate type fuel elements containing a uranium-zirconium-niobium alloy and clad with zircaloy experienced an average irradiation level of about $1600 \mathrm{Mwd} / \mathrm{mtU}$. The first SRE core, consisting of enriched-uranium metal slugs bonded with sodium-potassium in stainless-steel tubes, achieved an average irradiation level of 800 and a maximum in one tube of about $1300 \mathrm{Mwd} / \mathrm{mtU}$; the core was then damaged as a result of obstruction of coolant passages by a contaminant in the sodium coolant. In the first SM-1 core, consisting of highly enriched uranium clad with stainiess steel, 32 per cent of the contained $\mathrm{U}^{235}$ has been consumed. In the Materials Testing Reactor, aluminum-clad fuel elements containing an alloy of highly enriched uranium and aluminum are normally irradiated to the point where approximately 30 per cent of the $U^{235}$ is consumed.

As experience increases and technology improves, irradiation levels may exceed present guarantees. Development of fuel elements that can withstand higher ir radiation levels and that can be fabricated at lower costs is very important in fuel-cycle economics.

\section{Cost of Fuel-element Fabrication}

Fuel-element fabrication is taken to include all steps in the manufacture of completed fuel elements, including chemical, metallurgical, and mechanical processing, inspection, testing, and scrap recovery. The cost of fabrication per unit mass of uranium depends on the design of the fuel element; its size, dimensional tolexances and other specifications; enrichment of the uranium, kind of alloying and cladding materials; number of fuel elements fabricated; and use charge or working-capital charge. For example, uranium oxide pellets as formed may cost one-third less than pellets ground to precise tolerances. Criticality hazards increase with the enrichment of the uranium, resulting in reduced batch sizes and increased unit costs.

Estimates of the cost of fabricating a reactor core are not always clear as to whether they include costs of spare fuel elements and control rods and use charges on enriched uranium during fabrication. In compiling Table 9 , unit costs were obtained by dividing the reported fabrication cost for the first core by the number of kilograms of uranium (or uranium plus thorium) in the core.

The charges for fuel-element fabrication on which standard fuel-cycle costs are based in the arrangement with Euratom are $\$ 100$ per kilogram of uranium clad with stainless steel and $\$ 140$ per kilogram of uranium clad with zirconium, for uranium oxide with $U^{235}$ assays not greater than 3 per cent and diameters between 0.25 and $0.50 \mathrm{in}$. For $\mathrm{U}^{235}$ assays between 3 and 5 per cent, corresponding fabrication charges are increased by $\$ 8$ for each percentage above 3 per cent.

The costs of fabricating enriched uranium into fuel elements to meet specified standards of performance should decrease substantially in the future as a result of technological improvements and large-scale production. However, increasing the irradiation levels and temperatures to be attained may increase fabrication costs, at least temporarily.

\section{Cost of Transporting Irradiated Fuel Elements}

An example of the cost of transporting irradiated fuel elements in the United States from a reactor site to a chemical processing plant is given here. It is assumed that the cooling time between discharge of the fuel elements from the reactor and their shipment is 120 days or more, that all shipments will comply with that portion of the Code of Federal Regulations 
Table 9-FIRST CORES FOR POWER REACTORS

\begin{tabular}{|c|c|c|c|c|}
\hline $\begin{array}{l}\text { Fuel type and } \\
\text { nuclear plant }\end{array}$ & $\begin{array}{l}\text { Diameter or } \\
\text { thickness of } \\
\text { fuel element, } \\
\text { in. }\end{array}$ & $\begin{array}{c}\mathrm{U}^{235} \\
\text { assay, } \%\end{array}$ & $\begin{array}{l}\text { Uranium } \\
\text { in reactor, } \\
\quad \mathrm{kg}\end{array}$ & $\begin{array}{c}\text { Fabrication } \\
\text { cost of } \\
\text { uranium, }{ }^{b} \$ / \mathrm{kg}\end{array}$ \\
\hline \multicolumn{5}{|l|}{$\begin{array}{l}\text { Uranium oxide, } \\
\text { zircaloy clad }\end{array}$} \\
\hline Shippingport, blanket & 0.465 & 0.71 & 12,790 & 560 \\
\hline Carolinas-Virginia & 0.50 & 2.0 & 3,280 & 510 \\
\hline Dresden & 0.563 & 1.5 & 52,600 & 190 \\
\hline Fumboldt Bay & 0.563 & 2.0 & 13,840 & 190 \\
\hline SENN & 0.563 & 2.0 & 41,400 & 140 \\
\hline BONUS, boiler & 0.500 & 1.85 & 2,550 & $140^{\circ}$ \\
\hline \multicolumn{5}{|l|}{$\begin{array}{l}\text { Uranium oxide, } \\
\text { stainless steel clad }\end{array}$} \\
\hline Yankee & 0.340 & 3.4 & 20,840 & 200 \\
\hline EGCR & $0.32 \times 0.75^{\mathrm{d}}$ & 2.55 & 9,860 & 150 \\
\hline BONUS, superheater & 0.542 & 3.5 & 1,630 & $125^{\mathrm{C}}$ \\
\hline Florida & 0.57 & 1.68 & 15,800 & 87 \\
\hline Big Rock Pointe & 0.388 & 3.2 & 7,690 & \\
\hline Saxton & 0.343 & 3.7 & 1,270 & \\
\hline \multicolumn{5}{|l|}{$\begin{array}{l}\text { Uranium oxide-stainless } \\
\text { steel cermet, } \\
\text { stainless steel clad }\end{array}$} \\
\hline SM-1 & $0.030^{f}$ & 93 & 24 & $4,600^{g}$ \\
\hline McMurdo Sound & 0.5 & 93 & 31 & 8,380 \\
\hline Vallecitos & $0.025^{f}$ & 93 & 24 & \\
\hline Pathfinder, superheater & $\begin{array}{c}0.458 \times 0.512 \text { and } \\
0.672 \times 0.726^{\mathrm{d}}\end{array}$ & 93 & 37 & h \\
\hline \multicolumn{5}{|l|}{$\begin{array}{l}\text { Uranium oxide } \\
\text { aluminum clad }\end{array}$} \\
\hline $\begin{array}{l}\text { Pathfinder, boiler } \\
\text { Uranium \& thorium oxide, } \\
\text { stainless steel clad }\end{array}$ & 0.418 & 1.8 & 6,500 & h \\
\hline Indian Point & 0.304 & 93 & $16,280^{i}$ & 435 \\
\hline Elk River & 0.452 & 93 & $4,000^{\mathrm{j}}$ & 105 \\
\hline \multicolumn{5}{|l|}{$\begin{array}{l}\text { Uranium \& thorium oxide, } \\
\text { in graphite }\end{array}$} \\
\hline \multicolumn{5}{|l|}{$\begin{array}{l}\text { Uranium metal, } \\
\text { stainless steel clad }\end{array}$} \\
\hline SRE & 0.79 & 2.78 & 3,000 & 100 \\
\hline \multicolumn{5}{|l|}{$\begin{array}{l}\text { Uranium alloys, } \\
\text { zircaloy clad }\end{array}$} \\
\hline Shippingport, seed $2(\mathrm{U}-\mathrm{Zr})$ & $0.069^{f}$ & 93 & 97 & 26,000 \\
\hline Fermi, core $(\mathrm{U}-\mathrm{Mo})^{1}$ & 0.158 & 25.6 & 1,900 & 640 \\
\hline EBWR $(U-Z r-N b)$ & $0.24^{\frac{f}{2}}$ & $1.44^{\mathrm{m}}$ & 5,500 & 144 \\
\hline \multicolumn{5}{|l|}{$\begin{array}{l}\text { Uranium alloys, } \\
\text { stainless steel clad }\end{array}$} \\
\hline Hallam $(U-M o)$ & 0.66 & $3.6^{n}$ & 27,600 & 110 \\
\hline Fermi, blanket (U-Mo) & 0.443 & 0.35 & 37,580 & 48 \\
\hline $\begin{array}{l}\text { EBR-II, core (U-fissium) } \\
\text { Uranium alloy, } \\
\text { aluminum clad }\end{array}$ & 0.174 & 48.6 & 350 & \\
\hline Piqua (U-Mo-A1) & $\begin{array}{c}3.11 \times 4.10 \text { and } \\
4.14 \times 5.13^{\circ}\end{array}$ & 1.94 & 6,550 & 89 \\
\hline
\end{tabular}


a Outer diameter of clad rod, unless otherwise noted.

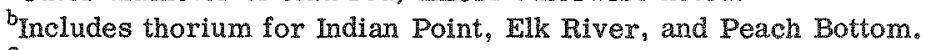

Assumed by reactor designer.

Inner and outer diameters of tube.

Twelve of the 143 rods per bundle have a diameter of $0.338 \mathrm{in}$, and a $\mathrm{U}^{235}$ assay of 2.8 per cent.

fThickness of plate.

${ }^{8}$ Cost of fabrication at Oak Ridge. A similar core being procured commercially will cost about twice as much.

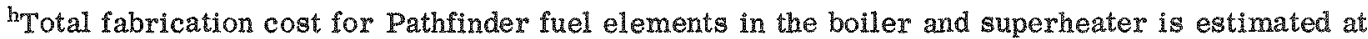
$\$ 950,000$, not including research, development, and testing.

includes $15,100 \mathrm{~kg}$ of thorium.

Includes $3820 \mathrm{~kg}$ of thorium.

${ }^{\mathrm{k}}$ Includes $1190 \mathrm{~kg}$ of thorium.

${ }^{1}$ The first core will have an additional cladding of stainless steel.

${ }^{m}$ of the 114 fuel assemblies, 8 contain normal uranium.

${ }^{n} A$ few of the fuel elements have a $U^{235}$ assay of 3.45 per cent.

Inner and outer diameters of finned tubes.

applicable to the shipment of radioactive materials, that adequate property insurance coverage will be provided, that couriers will not be required, and that casks are available on a rental basis. Cost of property insurance during shipment has been variously estimated from 0.5 to 2 per cent of the value of the special nuclear material in the fuel elements, and this range is used in the calculations. In the example given, a value of $\$ 300$ per kilogram of uranium is assumed for slightly-enriched irradiated fuel. Liability insurance and indemnity provisions already included in fixed charges on the nuclear power plant would cover the fuel elements during transportation to the chemical processing plant.

Transportation costs are estimated below for distances of about 3000 miles and for two cask sizes. The first is a 30 -ton cask with a capacity for irradiated fuel elements containing $2000 \mathrm{lb}$ of uranium. The second is a 70 -ton cask carrying $7600 \mathrm{lb}$ of uranium. The advantage of the larger cask is indicated by the lower ratio of total cask to uranium weight (18 vs. 30 ). Where requirements of nuclear safety, heat dissipation, etc., can be satisfied, the largest cask compatible with transportation and handling facilities appears to have an economic advantage.

\author{
Transportation costs in \\ dollars per kilogram of uranium
}

$$
\text { 30-ton cask } \quad 70 \text {-ton cask }
$$

Freight from reactor to processing plant Freight for return of empty casks

Cask rental

Property insurance

Total

$\begin{array}{cc}2.40 & 1.50 \\ 2.30 & 1.40 \\ 2.90 & 2.00 \\ 1.50-6.00 & 1.50-6.00 \\ 9.10-13.60 & 6.40-10.90\end{array}$

For a reactor in Western Europe, costs for shipment of irradiated fuel elements from Hamburg to Hanford have been taken in some of the Euratom calculations as $\$ 20$ per kilogram of contained uranium. This estimate was based on small shipping casks having a high ratio of the weight of cask to the weight of contained uranium and included costs of ocean freight and a courier charge. In a report of the Stresa Conference held in May 1959, the cost of transporting spent fuel elements from Europe to the United States was estimated at $\$ 18$ per kilogram of contained uranium.

The factors that contribute most to the uncertainties in these transportation costs are the insurance rates, the choice of cask size and weight, cooling time prior to shipment, and effect of negotiations on carrier rates. 


\section{Cost of Chemical Processing and Conversion}

After irradiation and cooling, fuel elements undergo chemical processing to extract source or special nuclear materials. A notice in the Federal Register of Mar. 12, 1957 (amended on Dec. 16, 1959), established AEC charges for chemical processing based on a conceptual plant with a capacity of one ton per day for normal or slightly enriched uranium and a reduced capacity for more highly enriched uranium.

Basic processing services include dissolution of irradiated fuel, separation and storage of fission products, and production of purified solutions of uranium and plutonium nitrates. AEC charges for these services are obtained by multiplying a fixed daily charge times the number of days required to process a given batch of fuel, including the time for start-up, shutdown, and clean up of the processing facilities. The daily charge when first announced in March 1957 was $\$ 15,300$ and was made up of $\$ 6850$ for depreciation and $\$ 8450$ for the cost of operation, waste storage, and overhead. These charges are subject to escalation. The depreciation portion is escalated on the basis of the Engineering News Record construction cost index, with the value of 694.8 for July 1956 as the base. The remaining portion is escalated according to the U.S. Bureau of Labor Statistics wholesale price index for inorganic chemicals with the value of 135.3 for July 1956 as the base. The daily charge computed as of August 1960 is $\$ 16,988$.

The processing rate in the conceptual plant depends on the $U^{235}$ assay of the unirradiated fuel, as shown in the following table:

$U^{235}$ assay of
unirradiated
fuel, \%
3 or less
4
5
6
7
8
10

15

\author{
Processing rate, \\ lgg uranium per day
}

1000

930

875

825

781

740

537

310

$$
\begin{gathered}
U^{235} \text { assay of } \\
\text { unirradiated } \\
\text { fuel, } \%
\end{gathered}
$$$$
20
$$$$
25
$$$$
30
$$$$
40
$$$$
50
$$$$
60
$$$$
80
$$

93
Processing rate, kg uranium per day

Linear interpolation may be used to determine processing rates for $\mathrm{U}^{235}$ assays not given in the table. There is an exception to the table in the case of highly enriched fuels of uraniumaluminum alloy of the type used in the Materials Testing Reactor, where the daily processing rate has been established as $400 \mathrm{~kg}$ of uranium plus aluminum, including end boxes.

The number of kilograms of uranium in a batch divided by the processing rate in kilograms per day gives the number of processing days required. The additional time needed for start-up, shutdown, and clean-up for each batch (turn-around time) is assumed to be not less than two days and not more than eight days and otherwise equal to the number of processing days to the nearest tenth.

The AEC has reserved the right to terminate chemical processing services when it determines that such services are commercially available at reasonable prices. Commercial prices will be greatly dependent on the technology used, the scale of operation, and the rate of plant amortization. Studies of the design and cost of chemical processing facilities are being made for the AEC and for others. Future uses of radioactive fission products may make it profitable to recover them from the processing of power-reactor fuel elements.

Chemical processing plants usually yield purified solutions of uranium nitrate and of plutonium nitrate, while the form to which AEC credits apply is the hexafluoride for uranium and the metal for plutonium. The AEC charge for converting uranium nitrate to hexafluoride is currently $\$ 5.60$ per kilogram of uranium for $U^{235}$ assays of 5 per cent or less and $\$ 32$ for 
assays above 5 per cent. The AEC charge for converting plutonium nitrate to metal is $\$ 1.50$ per gram of plutonium.

There will be some irrecoverable losses of uranium and plutonium in each step of processing and conversion. If AEC processing and conversion services are used, losses are assumed to be 1.3 per cent of the value of the uranium and 2 per cent of the value of the plutonium involved. The value of the uranium is based on the published $\mathrm{AEC}$ schedule of charges for material of the $U^{235}$ assay received at the processing plant. The value of the plutonium is based on the published AEC price for the material. When losses are included in the processing and conversion charges in this way, credits for uranium and plutonium are based on the amounts delivered to the AEC processing plant and not on the amounts subsequently recovered.

Two examples of processing and conversion charges are given below.

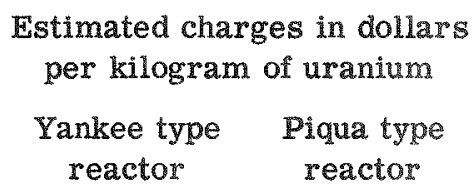

\begin{tabular}{lrr} 
Chemical processing time & 17.50 & 17.00 \\
Turn-around time & 6.60 & 17.00 \\
Conversion to $U F_{6}$ & 5.60 & 5.60 \\
Conversion to Pu metal & 7.40 & 4.10 \\
Loss of uranium & 4.20 & 2.10 \\
Loss of plutonium & 1.20 & 0.60 \\
\multicolumn{1}{l}{ Total } & 42.50 & 46.40
\end{tabular}

In both cases, it is assumed that the batch for chemical processing consists of one reactor core. In calculating the charge for loss of plutonium, a value of $\$ 12$ per gram has been used.

Similar estimates for other slightly-enriched reactors like Dresden, Hallam, CarolinasVirginia, Florida, and BONUS give total processing and conversion charges ranging from about $\$ 34$ to $\$ 50$ per kilogram of uranium. (Corresponding figures for highly-enriched reactors are much greater.) The portion of these charges that is for turn-around time in the chemical processing plant tends to be higher for the smaller reactors because of the lesser amounts of uranium involved. The turn-around charge also depends on how the spent fuel elements are batched for chemical processing. In some cases, this charge can be reduced by holding fuel elements to accumulate a larger batch. However, such a cost reduction needs to be weighed against increases in use and storage charges and increases in working capital resulting from delayed credit for plutonium.

\section{Use Charge for Leased Fuel}

Under the Atomic Energy Act of 1954, special nuclear material within the jurisdiction of the United States is the property of the Federal Government. This includes enriched uranium, plutonium, and $U^{233}$. The Government leases special nuclear material for peaceful uses, and the annual use charge is 4 per cent of the value of the material. If the nuclear fuel were sold to electric utilities, the investment in the fuel inventory would be included in the Materials and Supplies Account and treated as working capital, as discussed in that section.

The fuel inventory for a nuclear plant includes material in storage at the reactor site, under irradiation in the reactor, being cooled after discharge, in shipment to and storage at the chemical processing site, and undergoing chemical recovery and conversion. Fuel in the process of fabrication and shipment to the reactor site is not listed here because it is assumed that the fabricator includes the use charge on this material in his price for delivered fuel elements.

In the case of enriched uranium, the value of the material depends on the mass of total uranium and the $U^{235}$ and $U^{233}$ assays. As the uranium is irradiated in the reactor, its value 
changes. If this change is assumed to be linear with time, the average value is one-half the sum of the initial and final values. The utility pays the AEC every six months for the accumulated use charge, for uranium that has been consumed by burn-up or loss, and for reductions in value resulting from isotopic blending of different $U^{235}$ assays.

The total value of the fuel inventory is given by the following expression, where the fuel in the reactor is referred to as the core: Value of fuel inventory

$=$ (value of spare fuel)

+ (initial value of core) (ratio of time for storage of fresh fuel at reactor site to time for core irradiation)

$+1 / 2$ (initial plus final values of core)

+ (final value of core) (ratio of time for cooling, shipment, processing, and storage of spent fuel to time for core irradiation)

If a fraction $f$ of the core is discharged at each refueling and if a number $n$ of reactor discharges are accumulated to make one processing batch, the above expression should contain an additional term equal to $1 / 2 \mathrm{f}(\mathrm{n}-1)$ (final value of core).

Values of the uranium inventory are estimated for several reactor types in Table 10. The value of the uranium inventory tends to be greater for higher plant capacity, lower specific power, and higher $\mathrm{U}^{235}$ assays.

TABLE 10- ESTIMATED URANIUM INVENTORY VALUES FOR SEVERAL REACTOR TYPES

\begin{tabular}{lccccc}
\hline \multicolumn{1}{c}{ PIant type } & $\begin{array}{c}\text { Capacity in } \\
\text { net electric } \\
\text { megawatts }\end{array}$ & $\begin{array}{c}\text { Specific power } \\
\text { in net electric } \\
\text { kw per kg of } \mathrm{U}\end{array}$ & $\begin{array}{c}\mathrm{U}^{235} \text { assay, } \% \\
\text { Initial }\end{array}$ & $\begin{array}{c}\text { Value of ura- } \\
\text { nium inventory } \\
\text { in } \$ \text { millions }\end{array}$ \\
\hline Carolinas-Virginia & 17 & 4.1 & 2.0 & 0.99 & 0.6 \\
BONUS* & 16.3 & 3.9 & 1.85 & 0.90 & 1.1 \\
Florida & 50 & 3.2 & 3.50 & 2.29 & \\
Piqua & 11.4 & 1.8 & 1.68 & 0.68 & 2.2 \\
Dresden & 180 & 3.4 & 1.5 & 1.60 & 2.2 \\
Yankee & 110 & 5.3 & 3.4 & 2.65 & 12.3 \\
Hallam & 75 & 3.0 & 3.6 & 2.7 & 13.4 \\
\hline
\end{tabular}

*The lower $\mathrm{U}^{235}$ assays are for the boiler and the higher ones are for the superheater.

For BONUS, Piqua, and Hallam, the reactors are being constructed by the AEC and no use charge on the uranium inventory will be collected. In the other cases listed above, the reactors are privately owned but, except for Dresden, the use charge is waived by the AEC for the first five years of operation.

\section{Charge for Fuel Consumption}

Enriched uranium is leased domestically by the AEC, but the user pays for material lost or consumed. The fraction of the contained $U^{235}$ consumed prior to discharge of fuel elements depends on the reactor design, the initial $\mathrm{U}^{235}$ assay, and the irradiation level. The initial and the final assays determine the unit cost of burn-up, which can be computed from the published schedule of charges (see the Federal Register of Apr. 2, 1960). The burn-up cost is the difference between the charge for the uranium in fresh fuel and the credit for the uranium in spent fuel. The unit cost of burn-up increases with the initial $U^{235}$ assay and decreases as the irradiation level goes up. The variation with irradiation level is greater for normal and slightly enriched uranium than for higher assays and is quite small for highly enriched uranium.

For example, consider fuel elements containing uranium oxide clad with stainless steel for use in a pressurized-water reactor of the Yankee type. The initial $U^{235}$ assay is 3.4 per cent and the assay after irradiation to $8,200 \mathrm{Mwd} / \mathrm{mtU}$ is estimated at approximately $2.65 \mathrm{per}$ 
cent. About 98.6 per cent of the uranium initially present remains after irradiation. The burn-up cosit is then $\$ 15.60$ per gram of $U^{235}$ consumed.

Another example is for fuel elements containing uranium oxide clad with a zirconium alloy for use in a boilling-water reactor of the Dresden type. The initial $U^{235}$ assay is 1.5 per cent and the assay after irradiation to $9,000 \mathrm{Mwd} / \mathrm{mtU}$ is estimated at 0.88 per cent with 98.3 per cent of the initial uranium remaining. The burn-up cost is then $\$ 13.60$ per gram of $U^{235}$ consumed.

Charges will also be made for the consumption of plutonium or $\mathrm{U}^{233}$ provided by the AEC for use in power reactors.

\section{Credit for Plutonium and $U^{233}$}

Under the Atomic Energy Act, any special nuclear material within the United States is the property of the United States and a fair price shall be paid to any person lawfully producing such material. The domestic price in effect for plutonium delivered to the AEC through June 30,1962 , is shown below:

$\begin{array}{cc}\mathrm{Pu}^{240}, \% & \begin{array}{c}\text { Price of plutonium } \\ \text { metal, } \$ / \mathrm{g}\end{array} \\ 0 & 45.00 \\ 2 & 41.50 \\ 4 & 38.00 \\ 6 & 34.50 \\ 8 & 31.00 \\ 8.6 \text { and } & 30.00 \\ \text { over } & \end{array}$

The domestic price is $\$ 30$ per gram of plutonium metal, regardless of isotopic composition, delivered to the AEC during the period of July 1, 1962, through June 30, 1963. The price for plutonium purchased by the $\mathrm{AEC}$ from foreign countries and restricted to peaceful uses is to be the fuel value and is $\$ 12$ per gram of metal through June 30,1963 . This is based on an estimated value of plutonium compared with enriched uranium as fuel for reactors operating on neutrons of thermal energy. The AEC price for $U^{233}$ domestically and for foreign purchases is $\$ 15$ per gram of $U^{233}$ in the form of the nitrate through June $30,1963$.

An important question in regard to the development of economic nuclear power is whether a particular plutonium price will remove incentives for attaining high irradiation levels of fuel elements. This depends on other costs in the fuel cycle, such as the costs of fuel-element fabrication and chemical processing. Consideration of Yankee and Dresden type reactors indicates that, for plutonium prices of $\$ 30$ or less per gram of metal and fuel-element fabrication costs of $\$ 100$ or more per kilogram of uranium, the net cost of the fuel cycle decreases with increasing irradiation level throughout the operating range presently anticipated. For much higher plutonium prices or much lower fuel-element fabrication costs, the curve of net fuel-cycle cost vs. irradiation level may pass through a minimum in the anticipated operating range, where it would be economic to discharge the fuel elements.

Another important aspect of a plutonium price is its effect on the economics of recycling plutonium as a reactor fuel. There would be no immediate economic incentive to recycle plu tonium in power reactors if the plutonium could be sold at a price higher than its fuel value. However, there would still be strong incentives to develop methods of recycling plutonium in anticipation of a time when its fuel value could prevail.

A high price for plutonium tends to favor reactors with a high ratio of plutonium formation to $U^{235}$ burn-up, such as heavy-water or fast reactors. A high price for plutonium compared with the price for $U^{233}$ tends to discourage the construction of reactors producing $U^{233}$.

$A E C$ laboratories and others are studying the value of plutonium and $U^{233}$ as reactor fuel, compared with uranium enriched in $U^{235}$. It has been shown that the relative values of these materials depend on the type and design of the reactor or combination of reactors in which the fuel is to be used. For examples, see reports $C F-59-5-106, C F-60-2-34$, and $C F-60-4-79$ 
from the Oak Ridge National Laboratory, HW-59758 REV from Hanford Atomic Products Operation, and NAA-SR-4812 from Atomics International.

\section{Total Fuel-cycle Costs}

The fuel-cycle costs given in Table 11 were computed for a pressurized-water reactor of the Yankee type, having a thermal efficiency of 28 per cent. The fuel elements are assumed to be clad with stainless steel and to contain uranium dioxide with such $U^{235}$ assays as are necessary to provide reactivity for achieving given irradiation levels. The reactor-physics calculations were made under the Fuel Cycle Study Project at the Massachusetts Institute of Technology (see report NYO-2128).

\section{Table 11 - ESTIMATED FUEL CYCLE COSTS FOR A YANKEE TYPE PRESSURIZED-WATER REACTOR}

(In mills per kilowatt-hour)

\begin{tabular}{ccccccccc}
\hline $\begin{array}{c}\text { Irradiation } \\
\text { level, } \\
\text { Mwd/mtU }\end{array}$ & $\begin{array}{c}\text { Initial } \\
\mathrm{U}^{235} \\
\text { assay, } \\
\%\end{array}$ & $\begin{array}{c}\text { Fuel-element } \\
\text { fabrication }\end{array}$ & Transport & $\begin{array}{c}\text { Chemical } \\
\text { processing } \\
\text { and } \\
\text { conversion }\end{array}$ & $\begin{array}{c}\mathrm{U}^{235} \\
\text { burn-up }\end{array}$ & $\begin{array}{c}\text { Pu } \\
\text { credit }\end{array}$ & $\begin{array}{c}\text { Use } \\
\text { charge }\end{array}$ & Total \\
\hline 2,500 & 2.38 & 5.96 & 0.60 & 2.21 & 2.85 & -1.37 & 0.75 & 11.00 \\
5,000 & 2.55 & 2.98 & 0.30 & 1.19 & 2.55 & -1.26 & 0.52 & 6.18 \\
7,500 & 2.73 & 1.98 & 0.20 & 0.85 & 2.40 & -1.20 & 0.46 & 4.69 \\
10,000 & 2.90 & 1.49 & 0.15 & 0.66 & 2.29 & -1.07 & 0.44 & 3.96 \\
12,500 & 3.10 & 1.19 & 0.12 & 0.55 & 2.20 & -1.04 & 0.43 & 3.45 \\
15,000 & 3.27 & 0.99 & 0.10 & 0.48 & 2.15 & -0.99 & 0.43 & 3.16 \\
20,000 & 3.63 & 0.74 & 0.07 & 0.38 & 2.05 & -0.91 & 0.45 & 2.78 \\
25,000 & 3.98 & 0.60 & 0.06 & 0.33 & 1.98 & -0.86 & 0.47 & 2.58 \\
\hline
\end{tabular}

Costs per kilogram of uranium are assumed here to be $\$ 100$ for fabricating fuel elements and $\$ 10$ for transporting irradiated fuel elements from the reactor to the chemical processing plant. The cost of chemical processing and conversion is taken as $\$ 33.90$ per kilogram of uranium, including losses, plus $\$ 1.74$ per gram of plutonium, including losses. The cost of $\mathrm{U}^{235}$ burnup is based on the AEC published schedule of charges for enriched uranium, the credit for plutonium is assumed to be $\$ 12$ per gram, and the use-charge rate is taken as 4 per cent per annum. In computing the use charge, it is assumed here that use charge during fabrication of fuel elements is included in the costs of fabrication, that replacement fuel elements are held at the reactor site for three months waiting to be loaded into the reactor, that spare fuel elements amount to 5 per cent of a reactor loading, that the cooling time after irradiation is four months, and that the time required for shipping, chemical processing, and conversion of ir radiated fuel is two and one-half months.

If the thermal efficiency were increased from 28 per cent to 35 per cent, all the costs in Table 11 would be reduced by 20 per cent and the total fuel-cycle cost would be decreased by 2.2 to 0.5 mills per kilowatt-hour. If the plutonium price per gram of metal, instead of $\$ 12$, were taken as the minimum of $\$ 30$ in effect domestically through June 30,1963 , the total fuelcycle cost would be decreased by 2.0 to 1.3 mills per kilowatt-hour.

Total fuel-cycle costs have also been calculated using design information for the Florida, BONUS, Dresden, Hallam, Piqua, and Carolinas-Virginia reactors. The results, which are subject to considerable uncertainty, range from about 3 to 11 mills per killowatt-hour. The major source of this wide variation is the quoted costs of fuel fabrication, which differ greatly even for apparently similar designs of fuel elements. This may be due to changes in fabrication costs with time and volume of operation, variances in specifications, and differences between estimates and contract prices. Another very significant factor in total fuel-cycle costs is the irradiation level; a value is assumed for each reactor but will be known only as a result of operating experience. 


\section{COST OF OPERATION AND MAINTENANCE}

\section{General}

At the present time, there is not much information on the cost of operation and maintenance of nuclear power plants. The Shippingport station had the following expenses in this category during the year ending on June 30, 1959:

$\begin{array}{lcc} & \begin{array}{c}\text { Cost of operation and maintenance } \\ \text { In thousands } \\ \text { of dollars }\end{array} & \begin{array}{c}\text { In mills per } \\ \text { kilowatt-hour* }\end{array} \\ \text { Operations } & 699 & 2.72 \\ \quad \text { Station labor } & 513 & 1.99 \\ \quad \text { Supplies, health, safety, etc. } & & \\ \text { Maintenance } & 68 & 0.27 \\ \quad \text { Supervision and engineering } & 32 & 0.12 \\ \text { Structures and improvements } & 197 & 0.77 \\ \text { Reactor and steam generating equipment } & & 0.46 \\ \text { Turbine-generator and other electrical } & 119 & 6.33 \\ \quad \text { equipment } & 1628 & \\ \text { Total } & & \end{array}$

* Based on the actual plant factor of 48.9 per cent for this period.

Since the Shippingport reactor is the first of its kind and since the plant is being used for experimental purposes, these costs are not expected to be representative of commercial stations. The cost in mills per kilowatt-hour depends on the plant factor, which is usually assumed to be 70 or 80 per cent for nuclear plants. If the plant factor had been 80 per cent instead of 48.9 per cent for the period considered above, the total cost of operation and maintenance would have been 3.87 mills per kilowatt-hour.

The respective operators have estimated that the cost of operation and maintenance will be 4.5 mills per kilowatt-hour for the Carolinas-Virginia plant, 2.0 for Yankee, 1.9 for Fermi, and 1.2 for Big Rock Point. Consolidated Edison has allowed 0.9 mill per kilowatt-hour for operation and maintenance of the Indian Point plant, compared with 0.63 mill for the actual cost at a fairly new conventional steam plant, but has indicated that years of operation are required before there will be a sound basis for estimating such costs in the nuclear case.

The cost of operation and maintenance will depend on the type of nuclear power plant and on the design and arrangement of equipment, especially as these affect the ease and speed with which maintenance and refueling operations can be performed. Operation and maintenance costs should decrease as operating experience is gained. Estimates made in advance of acquiring such experience will continue to be uncertain.

Employees responsible for operation and maintenance of a nuclear power plant must be specially trained for their jobs. Anticipated costs of training personnel prior to and chring early operation are reported for various nuclear plants as follows:

Piqua

Hallam

Yankee

BONUS

Florida

$$
\text { in thousands of dollars }
$$

\section{Plant}

Peach Bottom

Pathfinder

EGCR

Dresden
Cost of employee training in thousands of dollars 
At present, it is not clear how these initial training costs will be treated for accounting and rate-making purposes. They are given here rather than under construction costs on the supposition that they will be considered as operating expenses over a period of a few years. As such, they will not represent a continuing charge over the life of the plant and are not included in this report in computing costs of nuclear power in mills per kilowatt-hour. Costs of training replacement personnel will be a continuing expens?, presumably included under operation and maintenance, but the annual average should be only a small fraction of the figures quoted above.

\section{Moderator and Coolant Make-up}

The cost of moderator and coolant make-up is applicable to those reactors that incur losses of such materials having appreciable value. The losses may be economically significant for reactors cooled with heavy water or organic liquids. Losses are assumed to be minimized by recovery and purification of these materials, where feasible; costs of such operations are generally small compared with make-up costs.

In a study of a heavy-water-cooled reactor by the Carolinas-Virginia group, the annual loss of heavy water was estimated at 1 per cent of the inventory, resulting in a make-up cost of about 0.2 mill per kilowatt-hour. For the CANDU reactor design, it has been stated that an annual loss of 2 per cent of the heavy-water inventory lies in the realistic range and that the corresponding make-up cost would be 0.17 mill per kilowatt-hour. Various studies of heavy-water-cooled reactors by Sargent \& Lundy and by the du Pont Company indicate annual losses of 2 to 5.6 per cent of the heavy-water inventory and malke-up costs of 0.25 to 0.5 mill per kilowatt-hour, depending on the design and size of the reactor, the pressure and temperature of the heavy water, whether a direct or indirect cycle is used for steam generation, and whether losses due to spills and operating errors are included. Losses for the Savannah River production reactors are about 3 per cent per year.

Experience with the highly enriched second core of the Organic Moderated Reacior Experiment in Idaho, which is cooled and moderated by an organic liquid, has shown a make-up rate of about $55 \mathrm{lb}$ of the organic material per thermal megawatt day. At a cost of $\$ 0.17 \mathrm{per}$ pound of the material and a thermal efficiency of 30 per cent, this would amount to 1.3 mills per electrical kilowatt-hour. However, the make-up rate and cost per kilowatt-hour for this reactor experiment are expected to be cut in half for a large power reactor using slightly enriched uranium, where a smaller fraction of the energy would be absorbed in the coolant.

\section{TOTAL GENERATING COST}

Because of the many variables and uncertainties discussed in the preceding sections, no firm answers can be given at this time for the total cost of generating nuclear power. Summarized below is a range of estimated costs for privately-owned nuclear plants that utilize a pressurized water or boiling water reactor, that have a net capacity of around $150 \mathrm{Mw}(\mathrm{e})$, and that are similar in design to such plants presently operable, being built, or planned for early construction. (Although no organic-cooled reactor of this size is presently under construction, it would probably give total generating costs in the same range.) For purposes of comparison, corresponding figures are shown for fossil-fuel plants of about the same capacity.

The annual fixed charge on construction cost is taken as 15 per cent for nuclear plants and 14 per cent for fossil-fuel plants. The annual fixed charge on the investment in fuel fabrication for a nuclear plant is taken as 11 per cent and the annual use charge on the value of the uranium inventory as 4 per cent. Costs of research and development, electric substations, and transmission facilities are not included.

The ranges given represent typical generating costs but do not cover the entire gamut of such costs. For example, computed fuel costs for a nuclear plant may be greater if based on the charge for fabrication of the first core. The cost of building fossil-fuel plants may be less in areas where the climate permits outdoor type construction. Also, the cost of fossil fuel may be less for plants situated near coal mines or gas fields. 
Construction cost per net electrical kilowatt

plant factor

Cost in mills per kilowatt-hour

Fixed charges on construction cost

Fuel costs

Operation and maintenance

Total generating cost

$$
\begin{aligned}
& \text { Nuclear } \\
& \text { plant }
\end{aligned}
$$

$$
\begin{gathered}
\$ 300-\$ 400 \\
80-70 \%
\end{gathered}
$$

$6.5-10.0$

$3,5-5.5 *$

$1.0-2.0$

$11.0-17.5$

$$
\text { Fossil-fuel }
$$

plant

$\$ 150-\$ 200$

$80-70 \%$

$3.0-4.5$

$2.0-4.0 \dagger$

$0.5-1.0$

$5.5-9.5$

*Includes costs of fuel cycle and fixed charges on investment in fuel fabrication.

$\dagger$ Based on fossil-fuel costs of 20 to 40 cents per million Btu and a plant heat rate of 10,000 Btu per net electrical kilowatt-hour.

The Eleventh Steam Station Cost survey reported in the journal, Electrical World, on Oct. 5,1959 , included five cases where conventional stations each consisted of a single generating unit of capacity ranging from 100 to $156 \mathrm{Mw}(\mathrm{e})$ (nameplate rating), with annual fixed charges from 12.4 to 18.2 per cent per annum. Their total generating costs ranged from 5.2 to 8.1 mills per kilowatt-hour for plant factors from 69 to 87 per cent. These stations started operations in 1956 and 1957; construction costs would be higher for similar plants built more recently. However, it is clear that the total generating costs estimated in the above table for nuclear plants are not yet competitive with corresponding costs for fossil-fuel plants in the United States.

The largest single factor in the cost of electricity from these nuclear plants is the high fixed charges arising from the high construction costs. This effect may be somewhat reduced if the plants can operate above their design power levels. Where a utility system can justify the installation of a nuclear plant having a design capacity considerably greater than $150 \mathrm{Mw}(\mathrm{e})$, the fixed charges in mills per kilowatt-hour should be significantly less than those given above. Technological improvements and standardization of design should also reduce construction costs of nuclear plants, but may not bring them down to the level of conventional plants.

Among the fuel costs, a large item for reactors using enriched uranium is the cost of fabricating the fuel elements. This is a profitable area for research and development. Increased experience may permit simplification of design and relaxation of tight specifications for fuel elements. As the nuclear industry grows, the effects of mass production should reduce a number of the costs of the fuel cycle. Some of these improvements will undoubtedly be incorporated in existing reactors, so that the average fuel costs over the life of the plant may be considerably less than the initial costs. The inventory charge for enriched uranium, the costs of $U^{235}$ burnup, heavy water, chemical reprocessing and conversion, and the credit for plutonium are all determined in the United States by the AEC at present.

\section{OBJECTIVE FOR COMPETITIVE NUCLEAR POWER IN THE UNITED STATES}

One of the AEC objectives in the Civilian Power Reactor Program is to "reduce the cost of nuclear power to levels competitive with power from fossil fuels in high energy cost areas of this country within ten years" (by 1968). For this purpose, high-energy-cost areas have been defined as those in which the cost of fossil fuels to utilities is at least 35 cents per million Btu. It is useful to determine the location and electrical requirements of such areas to establish a basis for projections into the period after 1968 .

Data on fuel costs and plant size have been compiled from the 1959 issue of Steam-Electric Plant Construction Cost and Annual Production Expenses, published by the FPC. In that report, fuel cost data is given for 495 electric plants representing 93 per cent of the net kilowatt-hours generated in 1959 by utilities in the United States. 
Table 12 gives the installed steam-electric capacity corresponding to various fuel costs in the eight FPC regions shown in Fig. 2. About 16 per cent of the total capacity was in areas where the fuel cost was over 35 cents per million Btu. Most of these high-cost areas were in Region I, which includes the New England states, New York, New Jersey, Maryland, Delaware, and part of Pennsylvania.

Table 12-INSTALLED STEAM-ELECTRIC CAPACITY CORRESPONDING TO VARIOUS FUEL COSTS IN THE EIGHT FPC REGIONS

\begin{tabular}{crrrr}
\hline \multicolumn{5}{c}{ Electrical megawatts of installed capacity } \\
FPC region & For fossil fuel costs per million Btu of: \\
\hline I & Below 25 C & 25 c to 35€ & Over 35ఢ & Total \\
II & 1,485 & 7,622 & 14,465 & 23,572 \\
III & 15,489 & 10,445 & 419 & 26,353 \\
IV & 8,706 & 9,101 & 502 & 18,309 \\
V & 4,912 & 9,630 & 655 & 15,197 \\
VI & 13,561 & 729 & & 14,290 \\
VII & 623 & 547 & 106 & 1,276 \\
VIII & 421 & 112 & 15 & 548 \\
Total & 45,197 & 45,920 & 17,238 & 108,355 \\
\hline
\end{tabular}

Table 13-PLANT SIZE BY FUEL COSTS FOR 1959

\begin{tabular}{ccccr}
\hline $\begin{array}{c}\text { Plant size in } \\
\text { electrical }\end{array}$ & For fossil fuel costs per million Btu of: \\
megawatts & Below 25 c & 25 c to 35 c & Over 35c & Total \\
\hline $0-99$ & 3,982 & 3,321 & 1,464 & 8,767 \\
$100-149$ & 2,536 & 2,314 & 1,997 & 6,847 \\
$150-199$ & 3,737 & 2,519 & 1,347 & 7,603 \\
$200-299$ & 8,613 & 7,492 & 2,163 & 18,268 \\
300 and over & 26,329 & 30,274 & 10,267 & 66,870 \\
Total & 45,197 & 45,920 & 17,238 & 108,355 \\
\hline
\end{tabular}

The objective that nuclear power be competitive by 1968 with power generated by burning fossil fuel in high-cost areas has been further defined to apply to generating units having capacities of $300 \mathrm{Mw}(\mathrm{e})$. The FPC data specify the capacity of each plant but not of the individual units making up the plant. However, there is a trend toward large units for new installations as will be shown later. Table 13 shows a breakdown of plant size by fuel costs for 1959. About $9 \frac{1}{2}$ per cent of the total capacity is in plants of at least $300 \mathrm{Mw}(\mathrm{e})$ capacity and having fuel costs of over 35 cents per million Btu. There were twenty-three such plants, of which New York had eight, Pennsylvania five, Massachusetts three, New Jersey, Maryland, and California two each, and Connecticut one.

Comparison of the data in Table 13 with a similar tabulation for 1958 reveals that fuel costs have been reduced in the high-cost areas. Fuel costs exceeded 35 cents per million Btu for about 21 per cent $(20,760 \mathrm{Mw})$ of the tabulated capacity in 1958 , compared with 16 per cent $(17,238 \mathrm{Mw})$ in 1959 . There were 27 plants of $300 \mathrm{Mw}$ or larger that had fuel costs of over 35 cents in 1958 and only 23 such plants in 1959. 


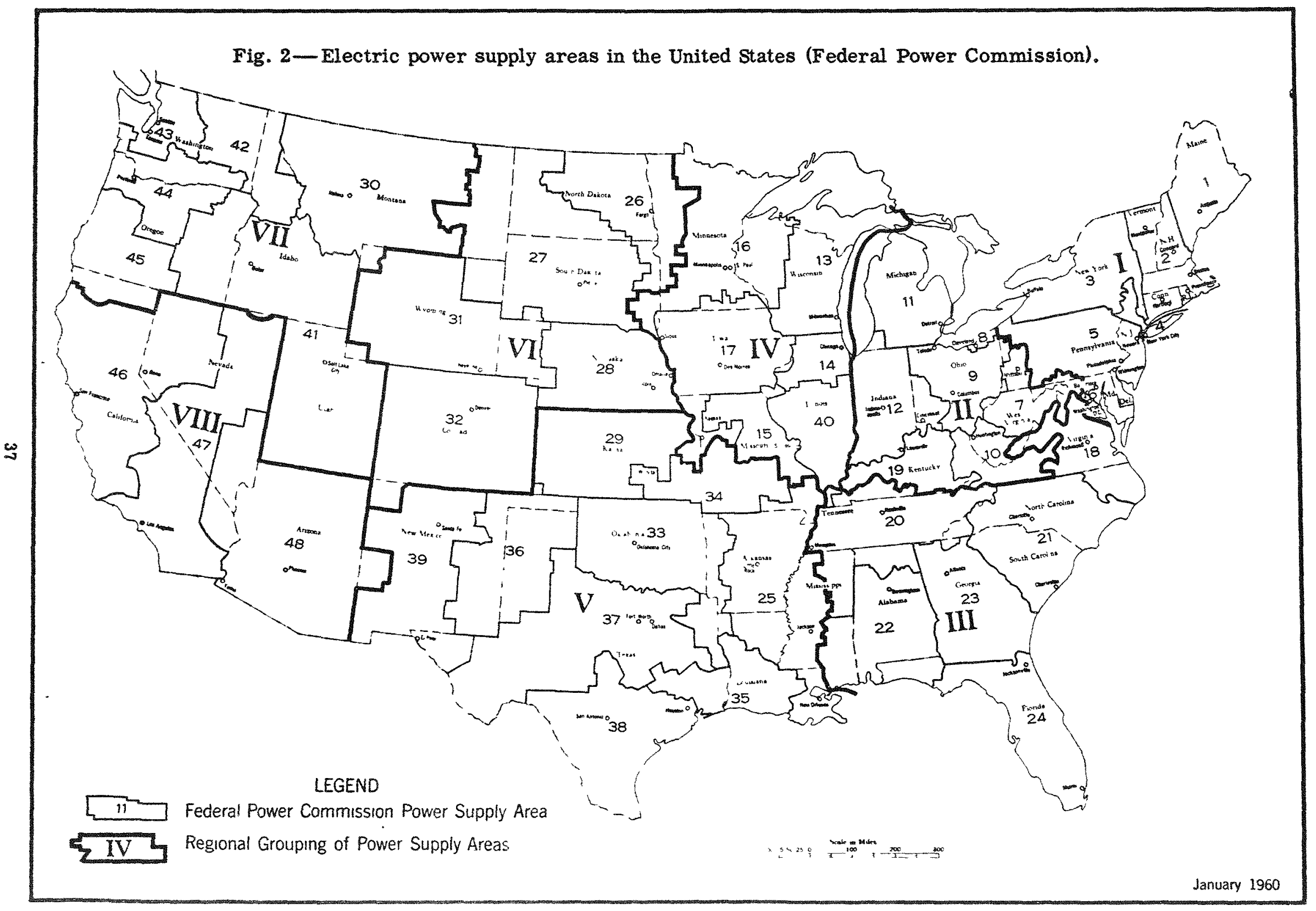


Information on the capacity of individual steam-electric units currently being installed by utilities in the United States is available from the Edison Electric Institute in its 27th Semi-Annual Electric Power Survey of April 1960 and is shown in Table 14. Over 12 per cent of the number and over 29 per cent of the capacity of the units being installed were in the size range of $300 \mathrm{Mw}$ and above.

Table 14-NUMBER OF SCHEDULED ADDITIONS OF STEAM-ELECTRIC UNITS AS OF APR. 1, 1960*

\begin{tabular}{lrrrrrrrr}
\hline & \multicolumn{9}{c}{ For unit sizes in electrical megawatts of: } \\
FPC region & $0-49$ & $50-99$ & $100-149$ & $150-199$ & $200-249$ & $250-299$ & $\begin{array}{c}300 \text { and } \\
\text { above }\end{array}$ & Total \\
\hline I & 4 & 1 & 5 & 13 & 4 & 2 & 11 & 40 \\
II & 8 & 1 & 4 & 10 & 3 & 3 & 3 & 32 \\
III & 2 & 4 & 4 & 3 & 11 & 4 & 4 & 32 \\
IV & 12 & 8 & 5 & 4 & 2 & 1 & 5 & 37 \\
V & 15 & 4 & 9 & 9 & 8 & 1 & 1 & 47 \\
VI & 6 & 1 & 2 & 1 & 0 & 0 & 0 & 10 \\
VII & 0 & 0 & 0 & 1 & 0 & 0 & 0 & 1 \\
VIII & 1 & 5 & 6 & 3 & 4 & 0 & 3 & 22 \\
\multicolumn{1}{c}{ Total } & 48 & 24 & 35 & 44 & 32 & 11 & 27 & 221 \\
\hline
\end{tabular}

*Includes units placed in service during first quarter of 1960 and includes nuclear as well as conventional units.

$\uparrow$ All but one unit being installed are hydroelectric and are therefore not included here.

The figures for 1959 therefore indicate that there are regions (especially Region I) in the United States where the costs of fossil fuels exceed 35 cents per million Btu for a significant portion of the installed electrical capacity and where individual generating units of $300 \mathrm{Mw}(\mathrm{e})$ or more are being installed. The goal that nuclear power must attain to become economically competitive in those regions and elsewhere will depend on prices of fossil fuels in the future. Such prices have fluctuated considerably in the past. Several recent studies of domestic energy supplies indicate no basis, from the standpoint of availability of fossil fuels, for an increase in the prices of coal and oil in the United States during the next decade or so, except for effects of rises in the general price level. This would mean that nuclear power must depend primarily on reductions in costs resulting from research, development, engineering, and production activities to become economically competitive with power from fossil fuels during that period. 


\section{APPENDIX}

\section{LIST OF NAMES, OWNERS AND OPERATORS, AND LOCATIONS OF NUCLEAR POWER PLANTS}

AGR (Advanced Gas-Cooled Reactor); United Kingdom Atomic Energy Authority; Windscale, Cumberland, England.

APS-1 (First Atomic Power Station of the USSR); Central Atomic Energy Utilization Board; Obninsk, Kaluga Region, USSR.

AVR (Arbeitsgemeinschaft Versuchs-Reaktor); North Rhine-Westphalia Research Center; Jülich, Federal Republic of Germany.

Berkeley Nuclear Power Station; Central Electricity Generating Board; Berkeley, Gloucestershire, England.

Big Rock Point Plant; Consumers Power Company; Big Rock Point, Mich.

BN-50; planned for construction at Ulyanovsk, USSR.

Bohunice; Ministry of Power and Water Economy; Bohunice, Czechoslovakia.

BONUS (Boiling Nuclear Superheater); United States Atomic Energy Commission and Puerto Rico Water Resources Authority; Punta Higuera, Puerto Rico.

BR-3 (Belgian Thermal Reactor No. 3); Centre d'Etudes de 1'Energie Nucléaire; Mol, Belgium.

Bradwell Nuclear Power Station; Central Electricity Generating Board; Bradwell, Essex, England.

Byeloyarsk (Ural Atomic Power Station); Ministry of Construction of Electric Power Stations; Byeloyarsk, Sverdlovsk Region, USSR.

CANDU (Canadian Deuterium Uranium) Reactor of Douglas Point Nuclear Power Station; Atomic Energy of Canada Limited and Hydro-Electric Power Commission of Ontario; Douglas Point, Ontario, Canada.

Carolinas-Virginia Tube Reactor; Carolinas-Virginia Nuclear Power Associates, Inc.; Parr, S. C.

Dounreay Fast Reactor; United Kingdom Atomic Energy Authority; Dounreay, Caithness, Scotland.

Dresden Nuclear Power Station; Commonwealth Edison Company; Morris, III.

Dungeness Nuclear Power Station; Central Electricity Generating Board; Dungeness, Kent, England.

EBR-II (Experimental Breeder Reactor No. 2); United States Atomic Energy Commission and Argonne National Laboratory; National Reactor Testing Station, Idaho.

EBWR (Experimental Boiling Water Reactor); United States Atomic Energy Commission and Argonne National Laboratory; Lemont, 111.

EDF-I(first unit of Chinon nuclear power station); Electricitê de France; Avoine, France.

EDF-2 (second unit of Chinon nuclear power station); Electricité de France; Avoine, France.

EDF-3 (third unit of Chinon nuclear power station); Electricite de France; Avoine, France.

EGCR (Experimental Gas Cooled Reactor); United States Atomic Energy Commission and Tennessee Valley Authority; Oak Ridge, Tenn.

Elk River Reactor; United States Atomic Energy Commission and Rural Cooperative Power Association; Elk River, Minn.

Fermi (Enrico Fermi Atomic Power Plant); Power Reactor Development Company and Detroit Edison Company; Lagoona Beach, Mich.

Florida (FWCNG Nuclear Power Plant); Florida West Coast Nuclear Group, Inc.; Polk County, Fla.

Hallam Nuclear Power Facility; United States Atomic Energy Commission and Consumers Public Power District; Hallam, Neb.

Hinkley Point Nuclear Power Station; Central Electricity Generating Board; Bridgwater, Somerset, Eng land.

Humboldt Bay Power Plant, Unit No. 3; Pacific Gas and Electric Company; Eureka, Calif.

Hunterston Nuclear Generating Station; South of Scotland Electricity Board; Hunterston, Ayrshire, Scotland.

Indian Point (Consolidated Edison Thorium Reactor); Consolidated Edison Company of New York, Inc.; Indian Point, N. Y. 
JAPC; Japan Atomic Power Company; Tokai-Mura, Japan.

JPDR (Japan Power Demonstration Reactor); Japan Atomic Energy Research Institute; Tokai-Mura, Japan.

Kahl Nuclear Power Station; Rheinisch-Westfälishches Elektrizitätswerk A.G. and Bayernwerk A.G.; $\mathrm{Kahl} / \mathrm{Main}$, Federal Republic of Germany.

Latina; Società Italiana Meridionale Energia Atomica (SIMEA); Latina, Italy.

McMurdo Sound (PM-3A); Bureau of Yards and Docks, United States Navy; McMurdo Sound, Antarctica.

Neuglobsow Plant; Office for Nuclear Research and Technology; Neuglobsow on Stechlinsee, Democratic Republic of Germany (East Germany).

NPD-2 (Nuclear Power Demonstration Station); Atomic Energy of Canada Limited and Hydro-Electric Power Commission of Ontario; Rolphton, Ontario, Canada.

Pathfinder Atomic Power Plant; Northern States Power Company; Sioux Falls, S. D.

Peach Bottom Atomic Power Station; Philadelphia Electric Company; Peach Bottom, Penn.

Piqua Organic Moderated Reactor; United States Atomic Energy Commission and City of Piqua; Piqua, Ohio.

Saxton Reactor Facility; Saxton Nuclear Experimental Corporation; Saxton, Penn.

SELNI Project; Società Elettronucleare Italiana; Vallegrande, Italy.

SENN Project; Società Elettronucleare Nazionale; Punta Fiume, Italy.

Shippingport Atomic Power Station; United States Atomic Energy Commission and Duquesne Light Company; Shippingport, Penn.

Sizewell Nuclear Power Station; United Kingdom Atomic Energy Authority; Sizewell, Suffolk, England.

SM-1 (Stationary Medium Power Plant No. 1); Corps of Engineers, United States Army; Fort Belvoir, $\mathrm{Va}$.

SRE (Sodium Reactor Experiment); United States Atomic Energy Commission, Atomics International, and Southern California Edison Company; Santa Susana, Calif.

Trawsfynydd Nuclear Power Station; Central Electricity Generating Board; Trawsfynydd, Wales,

Ulyanovsk Atomic Power Station (site of bolling water reactor and planned sodium graphite reactor); Central Atomic Energy Utilization Board; Ulyanovsk Region, USSR.

Vallecitos Boiling Water Reactor; General Electric Company and Pacific Gss and Electric Company; Pleasanton, Calif.

Voronezh Atomic Power Station; Ministry of Construction of Electric Power Stations; Voronezh Region, USSR.

Yankee Nuclear Power Station; Yankee Atomic Electric Company; Rowe, Mass. 